\title{
Turismo durante la Guerra Civil, 1936-1939: el impacto de la guerra en un sistema turístico en formación ${ }^{*}$
}

\author{
- Rafael Vallejo Pousada \\ Universidad de Vigo
}

\section{Introducción: ¿turismo durante la Guerra Civil española?}

Este trabajo parte de varios supuestos: el turismo como actividad económica y como práctica social en España durante el primer tercio del siglo XX es más importante de lo que generalmente se presupone; hasta la Guerra Civil, se están poniendo las bases del sistema turístico español contemporáneo. En 1936, España se muestra, a través de las cifras internacionales disponibles, como un país turístico emergente en el mercado turístico global; no es todavía un país líder, pero avanzó en sus posiciones durante los años 1930, de forma que en 1933 ocupa el lugar noveno entre los países turísticos receptivos; un país emergente en el que, no obstante, el turismo de los nacionales dentro y fuera del mismo era más importante que el de los extranjeros en él. ${ }^{1}$ En consecuencia, el que existiese ese sistema turístico en formación en 1936 significa que la guerra debió de haber repercutido en todos y cada uno de sus componentes, esto es, en las prácticas turísticas, las empresas, los organismos turísticos y, en fin, en los resultados de esta actividad económica. ¿De qué modo? ¿Cuánto? ¿Hubo continuidad en la administración turística de la Es-

* Este artículo se benefició de la financiación recibida en el marco del Proyecto de Investigación referencia: HAR2014-52023-C2-2-P, del Ministerio de Economía y Competitividad, y del Programa de Consolidación e Estructuración de Unidades de Investigación Competitivas, Grupos de Referencia Competitiva (GRC 2015/014), de la Xunta de Galicia. El autor agradece, por otra parte, las sugerencias recibidas de los evaluadores de la revista, que colaboraron a mejorar su redacción final.

1. Sobre la evolución económica del turismo en el primer tercio del siglo xx, Vallejo, Lindoso y Vilar (2016); sobre el sistema turístico español y la emergencia como país turístico, Va1lejo (2019, en prensa). 
paña nacional en guerra y la previa del Patronato Nacional de Turismo y la que le siguió desde 1939 en la Dirección General de Turismo?

El turismo durante la Guerra Civil ha sido objeto de diversos y valiosos estudios. No obstante, estos se han limitado a la política turística durante la contienda en relación con la propaganda al servicio de la misma y a las modalidades más destacadas del «turismo de guerra», sobre todo las llamadas Rutas Nacionales de Guerra promovidas en la España de Franco por el Servicio Nacional de Turismo (SNT). Nuestros supuestos de partida nos llevan a un planteamiento más general, y en cierto modo novedoso, sobre el turismo y la Guerra Civil. De ahí que para su desarrollo organicemos este trabajo en cinco grandes secciones. En la primera presentamos las principales líneas de evolución del turismo español entre 1900 y 1936 y cómo se configura un particular sistema turístico. En la segunda se estudian la coyuntura turística en el primer semestre de 1936 (¿fue normal respecto a los años previos?) y el desplome turístico desde el segundo semestre de 1936 hasta finales 1939, con sus variantes locales. En la tercera ofrecemos los rasgos fundamentales de la desestructuración provocada por la guerra en el incipiente sistema turístico español. En la cuarta y la quinta explicaremos cómo la guerra dio lugar, en medio de la contracción general de las prácticas y actividades turísticas, a nuevas modalidades de turismo; en particular, el llamado turismo de guerra. Analizaremos qué hay detrás de esta modalidad turística, esto es, qué fue el turismo de guerra en la España de 1936-1939, y estudiaremos uno de sus productos, ofertado oficialmente, las llamadas Rutas de Guerra de la España nacional. ${ }^{2}$ Acabaremos con unas conclusiones.

\section{Turismo y sistema turístico España entre 1900 y 1936: grandes líneas de evolución}

El turismo español hasta 1929 se encuentra en una fase preestadística. Salvo recuentos locales, debidos entes locales de turismo o los llamados sindicatos de iniciativa turística, asociaciones de fomento del turismo, como Fomento del Turismo de Barcelona, carecemos de cualquier tipo de estadísticas sobre el movimiento turístico en España, a excepción de las estimaciones sobre turismo exterior efectuadas por Tena, a partir de los datos oficiales acopiados por el servicio de estadísticas del Patronato Nacional de Turismo (PNT) y el servicio de estudios del Banco de España, por medio del funcionario Jainaga, para 1929-1934. Estas primeras estadísticas turísticas oficiales del PNT tienen, no obstante, varias limitaciones. La principal es que se refieren únicamente al turismo exterior y, por lo que parece, solo contabilizan los extranje-

2. Sobre las «Rutas», Correyero (2008), pp. 247-283, y Concejal (2014). 
ros hospedados en los hoteles, de forma que infravalorarían la cuantía real del mismo, al existir una importante oferta informal de alojamiento, como revela de forma muy clarificadora la isla de Palma de Mallorca, aunque esta realidad no se limitó a las Baleares. El diputado balear Alejandro Jaume sostenía en mayo de 1932 que «Mallorca desde hace algunos años atrae la atención de todo el turismo internacional. Las grandes agencias de viajes recomiendan al viajero la visita a Mallorca. Todos los hoteles de la isla están atestados de viajeros extranjeros durante el invierno», en tanto que «la mayor parte de las casas del Terreno y de Portopí se alquilan en invierno a los ingleses, franceses y alemanes». ${ }^{3}$

Ahora bien, la orfandad estadística en materia de turismo para el primer tercio del siglo XX ha empezado a ser superada recientemente, a partir de las estimaciones efectuadas por Rafael Vallejo, Elvira Lindoso y Margarita Vilar. Estas estimaciones permiten a día de hoy presentar las grandes líneas de evolución del movimiento turístico en este período, así como de la oferta y la demanda turística, o la posición del país en el mercado turístico internacional. ${ }^{4}$ Este salto adelante es posible por la utilización de metodologías y fuentes novedosas. Primero, el uso de las hemerotecas digitales, la cuantificación del fenómeno turístico a partir de palabras clave y la elaboración, con ellas, de índices turísticos o, más exactamente, de Índices de Intensidad Mediática del Turismo. Por otro, el empleo de la Contribución Industrial y de Comercio para cuantificar los principales elementos de la oferta turística, y de los anuarios financieros para aproximar la formación de capital en la hostelería y los balnearios creados como sociedades anónimas desde 1900. En tercer lugar hay que considerar una novedad metodológica: la identificación de los principales agentes que actúan desde la demanda y la oferta turística — pública y privada, Administraciones y empresas - y el análisis de cómo unos y otros van configurando lo que entendemos que constituye un sistema turístico en formación, que avanzó de forma notable a partir de mediados de la década de los veinte, cuando adquirió carta de naturaleza la «industria del turismo» y se reclamó una organización turística, con la correspondiente administración turística, que la impulsara. Las cifras y los testimonios de los años treinta son expresivos de este avance del sistema turístico español, cuyas líneas principales presentamos a continuación.

Un primer rasgo que destacar es que el turismo en España entre 1900 y 1936 siguió las mismas líneas de evolución que en los países turísticos de nuestro entorno: experimentó los mismos ciclos que el turismo internacional. Lo

3. Informe a las Cortes sobre las necesidades que generaba la explosión de la demanda turística en la isla de Mallorca, Archivo del Congreso de los Diputados. Las citas sobre el boom turístico balear a partir de 1929 son muchas; véanse Buades (2004) y Vives (2005).

4. Vallejo, Lindoso y Vilar (2016), Vallejo, Lindoso y Vilar (2017a y 2017b) y Vallejo (2019, en prensa). 
sabemos por el Índice de Intensidad Mediática del Turismo (gráfico 1), que dibuja este movimiento, y la comparación de los ciclos españoles con los ciclos identificados por los especialistas de la época para el turismo internacional, caso de F. W. Ogilvie (1933), A. J. Norval (1936) y J. L. Lickorish y A. G. Kershaw (1958), así como con la evolución del PIB de español y el de los dieciséis países más industrializados. ${ }^{5}$

El Índice de Intensidad Mediática del Turismo (IIMT) es de fácil elaboración. Parte de cuantificar la voz «turismo» en las hemerotecas digitales disponibles. El resultado lo vemos en el gráfico 1. En síntesis, este IIMT nos muestra que en España encontramos las cinco grandes fases turísticas que señalan la historiografía y los especialistas contemporáneos, entre 1900 y 1939: 1) 19001914: Fase de despegue del turismo moderno; 2) 1914-1924: Fase de contracción turística — que no se superó de manera clara hasta 1924-1925, aunque la recuperación se inició en 1919-1920 - ; 3) 1924-1930: Fase de «boom turístico», con un máximo en 1929, coincidiendo con la Exposición Iberoamericana de Sevilla y Exposición Universal de Barcelona, que es también el del peak year mundial; 4) 1931-1935: Fase republicana, de alta intensidad turística sometida a la crisis económica, con dos subfases, con desiguales comportamientos regio-

GRÁFICO 1 - Índice de Intensidad Mediática del Turismo. España y Galicia, 1900-1955 $(1913=100)$

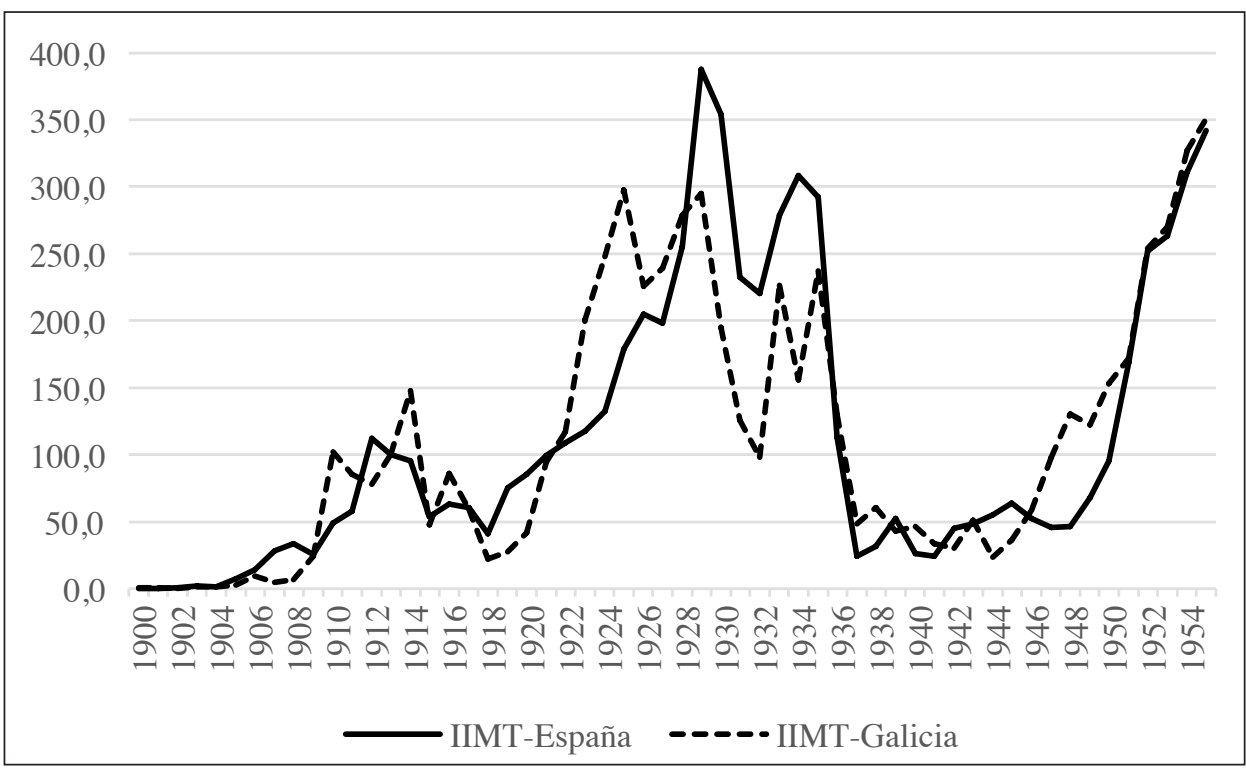

Fuente: IIMT-España: La Vanguardia, ABC/Blanco y Negro y Biblioteca Nacional de España (abril 2015). IIMT-Galicia: Galiciana (Hemeroteca digital de Galicia) (2017).

5. Véase Vallejo, Lindoso y Vilar (2016). 
nales: 1931-1932, de retroceso, identificado también por Ogilvie para el turismo internacional; y 1933-1935, de recuperación; y 5) 1936-1939, fase de hundimiento del turismo, debido a la Guerra Civil, a partir de julio de 1936, como se explicará luego.

Un segundo rasgo a destacar es que el turismo en España durante este período fue una práctica más de los nacionales (dentro y fuera del país) que de los extranjeros hacia España. En el cuadro 1 se estima que, en 1931-1934, los españoles que hicieron turismo en el país y en el extranjero representaron en torno al $90 \%$ de los turistas en España, de modo que los extranjeros supondrían el 10\% restante. Nos situamos en cifras medias de alrededor de 1.300 .000 españoles turistas, un 5,5\% de la población total (cuadro 5). No parecen cifras descabelladas. Con una renta per cápita casi igual en esas fechas (1926-1930), la población turística checoslovaca era el $15 \%$ de la total de su país $(14,7$ millones de habitantes. En Checoslovaquia, en 1926-1930, la media de turistas fue de 2,9 millones de personas; de ellas, el 13,5\% eran extranjeros (turismo receptivo), el $74,3 \%$ eran turistas checoslovacos en su propio país y el 12,3\%, turismo emisor. Como se ve, una composición no muy diferente a la del caso español. ${ }^{6}$

El siguiente rasgo general procede de las cifras de turismo internacional que hemos podido reconstruir recientemente, a partir de autores que manejan los datos que centraliza la Sociedad de Naciones. Según estas cifras, en la década de 1930, España no era un líder turístico mundial, pero avanzó posiciones de forma significativa, pues pasó del puesto trigésimo en 1931 al noveno en 1933. Esta posición del país entre los nueve primeros destinos del turismo mundial en 1933, acortando distancias con los países líderes, permiten considerarlo un país turístico emergente.

Un último rasgo del turismo español se deriva de la aproximación que hemos efectuado a la oferta turística y el stock turístico del país, en 1933 respec-

CUADRO 1 - Composición del turismo en España, 1931-1934

\begin{tabular}{lccc}
\hline \multicolumn{1}{c}{ Turistas } & $\begin{array}{c}\text { Turistas totales en } \\
\text { España, 1931-1934 } \\
\text { (media anual) }\end{array}$ & \% Total & $\begin{array}{c}\text { \% Población } \\
\text { española }\end{array}$ \\
\hline Receptivo: Extranjeros & 142.500 & 9,6 & 0,6 \\
\hline Interno: Españoles en España & 1.118 .562 & 75,7 & 4,7 \\
\hline Emisor: Españoles en el extranjero & 215.721 & 14,6 & 0,9 \\
\hline Turismo total & 1.476 .783 & 100,0 & 6,2 \\
\hline
\end{tabular}

Fuente: Vallejo, Lindoso y Vilar (2016).

6. El PIB per cápita de Checoslovaquia era en 1930 de 2.926 dólares y el de España, 2.620 dólares. Las cifras del turismo checoslovaco en Ogilvie (1933), pp. 152-159; las del PIB son las conocidas de Madisson. 
CUADRO 2 - Países turísticos en 1931 y 1933. Ingresos por turismo receptivo

\begin{tabular}{rlrrlr}
\hline \multicolumn{1}{c}{1931} & $\begin{array}{c}\text { Millones } \\
\text { dólares-oro }\end{array}$ & & 1933 & $\begin{array}{r}\text { Millones } \\
\text { francos }\end{array}$ \\
\hline 1 & Canadá & 241,6 & 1 & Francia & 3.000 \\
\hline 2 & Francia & 235,2 & 2 & Canadá & 2.000 \\
\hline 3 & Estados Unidos & 112,0 & 3 & Italia & 1.725 \\
\hline 4 & Reino Unido & 78,2 & 4 & Estados Unidos & 1.425 \\
\hline 5 & Italia & 72,8 & 5 & Suiza & 700 \\
\hline 6 & Suiza & 47,3 & 6 & México & 575 \\
\hline 7 & Austria & 36,6 & 7 & Reino Unido & 550 \\
\hline 8 & Bélgica & 34,8 & 8 & Alemania & 425 \\
\hline 9 & Alemania & 31,0 & 9 & España & 325 \\
\hline 10 & Cuba & 22,2 & 10 & Bélgica & 300 \\
\hline 11 & Checoslovaquia & 17,2 & 11 & Grecia & 250 \\
\hline 12 & Japón & 13,5 & 12 & Japón & 250 \\
\hline 13 & España & 12,4 & 13 & & \\
\hline 14 & China & 12,3 & 14 & & \\
\hline 15 & Suecia & 9,3 & 15 & & \\
\hline
\end{tabular}

Fuente: Société des Nations, Balance des Paiements (v.a.).

to a 1900, empleando la estadística de la CIC y los anuarios financieros. Según esta primera aproximación, el stock turístico del país, concretado en la oferta de «hotelería turística» de la CIC, los balnearios y casas de baños de la CIC, las agencias y oficinas de viajes sujetas a la CIC, los hoteles en forma de sociedad anónima, las sociedades anónimas balnearias y de aguas minero-medicinales y los establecimientos de hotelería públicos, se habría multiplicado por 2,5 entre 1933 y $1900 .^{7}$ Esta oferta se aceleró desde mediados de la década de 1920. Así, por ejemplo, las «agencias» que realizaban operaciones de «organizar excursiones, facilitar noticias sobre viajes, contratar o proporcionar billetes del ferrocarril, hospedaje, coches, etc.» pasaron, según la estadística de la Contribución Industrial y de Comercio, de 17 en 1927 a 61 en 1933.

Estos desarrollos descritos permiten afirmar que estamos, en el caso español, ante un sistema turístico en formación. Allí donde la intensidad turística fue mayor, como en San Sebastián, Barcelona, algunas localidades de la Costa Brava, Palma de Mallorca, Alicante, algunos pueblos en la periferia madrileña de la sierra o en el Pirineo catalán o aragonés, incluso vemos aparecer de la mano los sectores del turismo y la construcción, con las primeras

7. Vallejo, Lindoso y Vilar (2016). De 720 a 1.820 establecimientos. 
empresas inmobiliarias que compran suelo y generan espacios dedicados al veraneo y al ocio turístico. Se trata de «urbanizaciones» al «estilo moderno», con electricidad, agua corriente, teléfono y accesos al tráfico rodado, que ofrecen «playa perfecta, natación, regatas, pesca, caza, golf, tenis, polo, verbenas» $\mathrm{y}$ «hotel, restaurante (y) bar», como sucedía en Alcudia (Mallorca) en 1933. ${ }^{8}$ Ese dueto turismo-construcción formará parte estructural del modelo productivo español desde dos décadas más tarde, cuando se extendieron como setas los «apartamentos» turísticos y se maridaron el turismo y la especulación urbanística, con sus secuelas paisajísticas y medioambientales. ${ }^{9}$ Unos impactos que empezaron a verse, y a preocupar, de forma aún muy localizada, en la década de 1930, en geografías en proceso de turistificación, como la Costa Brava, como demuestra la Conferencia de la Costa Brava, celebrada en Girona el 10 de agosto de 1935, donde se abordó su planificación, con el fin de «evitar el peligro que la amenazaba», salvar «la esencia, las bellezas» de la misma, compatibilizando los derechos de los particulares (dueños de chalets, residencias turísticas y terrenos) y el interés público. ${ }^{10}$

En suma, la existencia de hotelería turística, con cadenas como HUSA gestionando más de 1.500 plazas hoteleras en 1935, la multiplicación de las agencias de viajes, la irrupción de empresas inmobiliarias en el negocio turístico, los primeros proyectos de planificación turística, así como la inclusión del turismo en los debates sobre los modelos de desarrollo regional, como vemos en la Conferencia Económica de Aragón, celebrada en octubre de 1933, indican que estamos en el caso español ante un sistema turístico en fase de conformación, con diferentes intensidades o desarrollos regionales. Fernando Betrán, representante del PNT en la asamblea de la Federación Española de Sindicatos de Iniciativa Turística (FESIT), celebrada en Barcelona en 1933, certificaba: «El concepto de turismo como industria ha nacido y se desarrolla entre nosotros. Hace unos años apenas existía». Y en enero de 1936, la Sociedad de Atracción de Forasteros de Barcelona (SAFB) constataba: «Ciertamente que está en marcha el turismo» en España. Es más, ya estallada la Guerra civil, el periódico republicano La Libertad sostenía que los gobernantes de la monarquía habían convertido "a España en un islote en la vida internacional, lo que contribuyó a que nuestro país [...] fuera totalmente desconocido, a excepción del turismo, que no cala en los pueblos más que para satisfacer su afán de lo superficial y de lo pintoresco». ${ }^{11}$ La asociación Espa-

8. Escalas (1933), p. 189. Para turismo y negocio inmobiliario en estos años en Mallorca e Ibiza, Buades (2004); para el litoral catalán, J. Cals (1989) y M. Tatjer (2009). También Vallejo (2019, en prensa).

9. Vallejo (2015), pp. 89-113.

10. Farreras (1973), p. 221.

11. Betrán, «Mis impresiones acerca de la Asamblea», en SAFB, Anuario de Barcelona 1933, 1934; «Junta General de la Sociedad de Atracción de Forasteros», Barcelona Atracción, 
ña-país de turismo receptivo ya circulaba en 1936. Pues bien, sobre este turismo «en marcha» y sobre aquel sistema turístico en formación cayó la Guerra Civil desde julio de 1936. Veamos con qué consecuencias.

\section{El turismo entre enero de 1936 y finales de 1939}

1936: Caída de la intensidad turística del país y normalidad en el turismo hasta el 18 de julio.

1936 empezó como un año difícil. Lo fue por razones internas y por el contexto internacional. El país vivió con el inicio del año una confrontación electoral muy polarizada en febrero de 1936, un clima de tensión y violencia social, de conflictividad socio-laboral, así como la preparación del golpe de Estado que llevó a la guerra en julio. En el ámbito internacional, las tensiones igualmente se agravaron. En octubre de 1935, Mussolini decidió conquistar Abisinia (Etiopía) y se inició la segunda guerra ítalo-abisinia, que duró siete meses y perturbó el tráfico comercial y de viajeros en el Mediterráneo. El 7 de marzo, Alemania invadió la Renania, controlada tras la Primera Guerra Mundial por Francia, que acudió a las urnas en junio y propició el triunfo del Frente Popular, mientras en Portugal, el Estado Novo de Salazar aplastaba y perseguía a la oposición, purgaba intelectuales y reprimía la resistencia con el exilio a la cárcel política de Tarrafal en Cabo Verde. Los portugueses se refieren a los de estos meses como «tempos ásperos».

La situación interna de Portugal y Francia, dos países con estrechas relaciones turísticas, pues de allí procedían más de la cuarta parte de los visitantes a España en los años treinta, amenazaba afectar las posibilidades turísticas de España en 1936. Los flujos de viajeros en la frontera franco-española eran intensos y, según datos de la Cámara de Comercio Francesa de Madrid de marzo de 1934, favorables a España desde 1932. ${ }^{12}$ Además, Francia había devaluado su moneda el 30 de marzo de 1935 - y volvió a hacerlo en octubre de 1936-.$^{13}$ La prensa de los países competidores, como Francia o Italia, se encargaba, por otra parte, de inflar las dificultades para viajar a España por sus perturbaciones políticas. A su vez, la guerra ítalo-abisinia de 1935-1936 tuvo efectos contradictorios, difíciles de medir, sobre el turismo español: provocó, por un lado, la disminución del tráfico crucerístico, y esto afectó ya en 1935 al turismo extranjero en Palma de Mallorca y otros puertos beneficiados de

297, 1936, pp. 72-73; y «Eficacia de una política de universalización», La Libertad, 9 de octubre de 1936, p. 1.

12. Datos recogidos en Fernández Fuster (1991), p. 278.

13. Leveillé-Nizerolle (1938), p. 104. 
aquel tráfico como Barcelona, pues se redujo la llegada de cruceros y disminuyó, en Mallorca, el número de estancias en hoteles (por eso se habla de crisis hotelera en Palma de Mallorca); ${ }^{14}$ por otra parte, recortó el turismo británico hacia Italia el invierno de 1935-1936, por las hostilidades de los italianos hacia los ingleses debido a la oposición británica a la ocupación de Abisinia, y hacia destinos como Egipto «por su proximidad a la zona actualmente en guerra». De este modo, aquellos turistas invernales no tuvieron «otro remedio que recurrir a otros países; y teniendo muy en cuenta que España en estos momentos era la nación que mayores garantías podía ofrecernos de seguridad y que por sus magníficas cualidades de clima invernal, sus bellezas naturales y sus riquezas artísticas la hacían el país ideal del turismo, nos decidimos este año por visitar España», confesaba uno de ellos. ${ }^{15}$

El estallido de la Guerra Civil a mediados de julio impide analizar el turismo de 1936 como si de un año normal se tratara. La guerra precipitó el derrumbe turístico, sobre todo del turismo exterior. Por eso lo adecuado es estudiar su primer semestre, el de normalidad. ¿Cómo repercutió el aludido clima político y social en el turismo en España y hacia España durante el primer semestre del año? Una forma de verlo es a través de la intensidad mediática del «turismo». ${ }^{16}$ Los datos obtenidos del diario La Vanguardia permiten las siguientes conclusiones. La primera es que el primer semestre de 1936 se mostró desde el punto turístico más flojo que los primeros semestres inmediatamente anteriores (con un retroceso del 27,5\% respecto al de 1935), aunque los de 1930, 1931 y 1932 habían manifestado una atonía similar, con retrocesos en la intensidad turística mediática del $20-25 \%$ respecto al primer semestre del año anterior (gráfico 2). El comportamiento fue peor en el primer trimestre del año 1936, si nos atenemos a la intensidad mediática del turismo, notablemente baja (cuadro 3). La polarización política con motivo de las elecciones de febrero y la escalada de tensión social, antes y después de las mismas, parecieron afectar a las expectativas de viaje de los españoles y, por supuesto, a la de los extranjeros hacia España. Los ingleses que pretendían veranear aquí, y pedían información por carta sobre el país, eran recurrentes en la preocupación por la seguridad: «Supongo que todas estas historias terribles que cuentan los periódicos sobre España [tras la victoria electoral de las izquierdas en febrero] son solo cosas de la prensa. En todo caso, ¿de verdad es seguro viajar a España?». ${ }^{17}$

14. La primera en los años de la República; Cámara Provincial de Comercio, Industria y Navegación de Palma de Mallorca, Memoria Comercial. Año 1935, Palma de Mallorca, Imprenta de Francisco Soler Prats, p. 6; Lavaur (1980), II, pp. 513-514.

15. Carta reproducida en El Heraldo de Madrid, 21 de febrero de 1936, p. 14.

16. Intensidad mediática es el número de veces que apareció la voz «turismo», contabilizada trimestralmente.

17. Carta recibida en Tossa de Mar por la hotelera británica Nancy Johnstone (2016), p. 137. 
GRÁFICO 2 - Intensidad mediática del turismo en los primeros semestres de 1907 a 1950. Tasa de variación anual (\%)

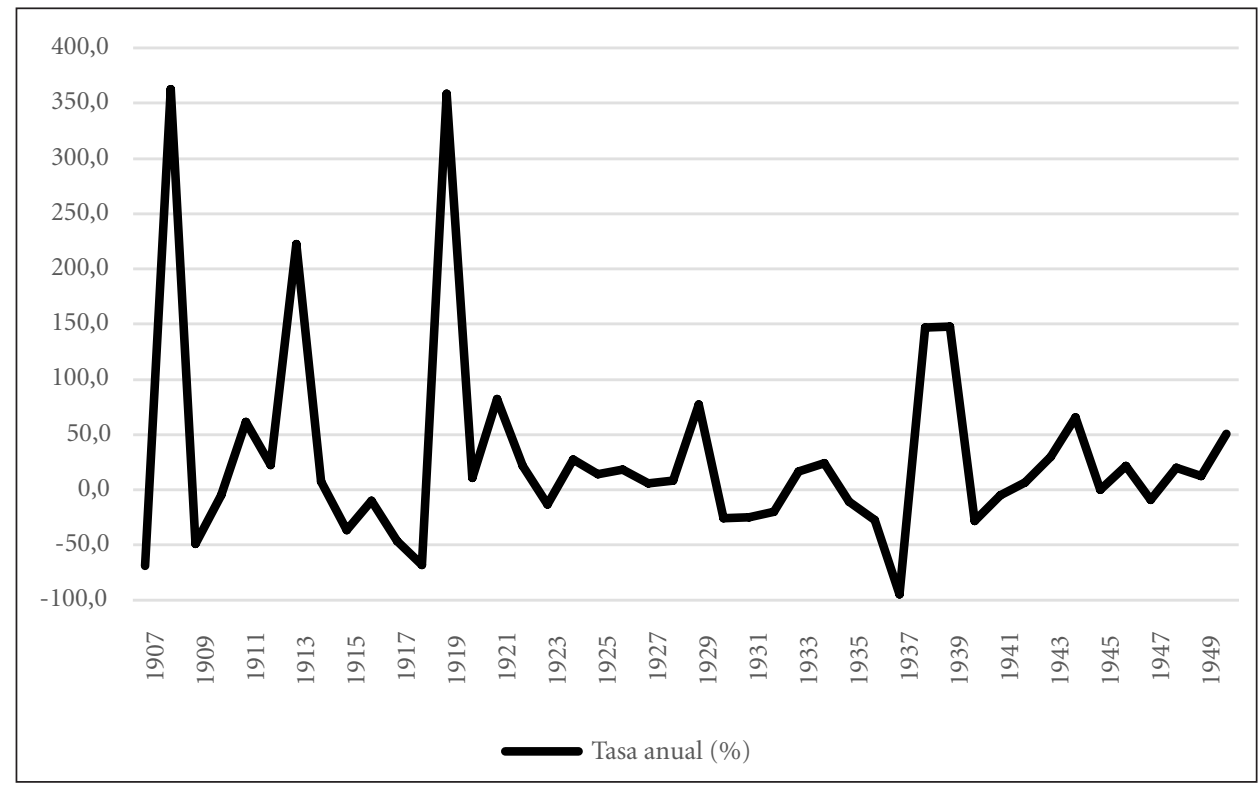

Fuente: La Vanguardia (Hemeroteca digital).

CUADRO 3 - Intensidad mediática del «turismo» por trimestres, 1913-1939(a)

\begin{tabular}{rrrrccc}
\hline & $\begin{array}{c}\mathbf{1 .}^{\text {er }} \\
\text { trimestre }\end{array}$ & $\begin{array}{c}\mathbf{2 .}^{\circ} \\
\text { trimestre }\end{array}$ & $\begin{array}{c}\text { 3. }^{\text {er }} \\
\text { trimestre }\end{array}$ & $\begin{array}{c}\mathbf{4 .}^{\circ} \\
\text { trimestre }\end{array}$ & $\begin{array}{c}\text { 1. }^{\text {er }} \\
\text { semestre }\end{array}$ & Año \\
\hline 1913 & 100 & 130 & 122 & 71 & 230 & 423 \\
\hline 1923 & 85 & 150 & 99 & 170 & 235 & 504 \\
\hline 1925 & 135 & 207 & 230 & 191 & 342 & 763 \\
\hline 1929 & 317 & 500 & 430 & 413 & 817 & 1.660 \\
\hline 1930 & 288 & 322 & 298 & 201 & 610 & 1.109 \\
\hline 1933 & 177 & 246 & 269 & 155 & 423 & 847 \\
\hline 1935 & 213 & 253 & 232 & 110 & 466 & 808 \\
\hline 1936 & 123 & 217 & 76 & 21 & 340 & 437 \\
\hline 1939 & 46 & 60 & 92 & 60 & 106 & 258 \\
\hline
\end{tabular}

Fuente: La Vanguardia (hemeroteca digital).

Nota: (a) Número de veces que aparece la palabra «turismo». 
Ahora bien, durante el segundo trimestre de 1936, el ambiente turístico remontó de forma apreciable. La intensidad mediática fue menor que en años previos, pero casi el doble que la del primer trimestre (cuadro 3).

En París, uno de los mayores centros irradiadores del turismo internacional, tras las elecciones legislativas de mayo, la campaña antiespañola que «determinada prensa» sustentaba en los problemas del «orden público» en España, se moderó y se rebajaron las «noticias tendenciosas». Los responsables de la Oficina de Turismo española en París vaticinaban una «temporada veraniega» hacia España «muy intensa», y otro tanto se percibía en medios diplomáticos, hasta el punto de que el cónsul en Hendaya proponía al embajador en París que se abriera una oficina del PNT en la costa vasco-francesa. ${ }^{18}$ Desde niveles algo inferiores en principio a los de 1935, el hecho es que respecto al turismo se respiraba un ambiente de normalidad y buenas expectativas en las semanas previas al golpe militar de julio. En Tossa del Mar, por ejemplo, los británicos Leonard y Nancy Jonhstone, que habían abierto un hotelito en 1934, constataban que

pese a las noticias alarmistas tuvimos el hotel lleno toda la primavera. [...] Nuestra segunda temporada de verano prometía ser buena. Ya casi teníamos reservado todo mayo y junio y empezábamos a tener reservas para julio y agosto. Aunque el año anterior tuvimos agosto lleno mucho antes, en general las historias alarmistas de la prensa no estaban afectándonos; al contrario, de no ser por ellas nos habríamos visto desbordados. ${ }^{19}$

Barcelona, por su parte, continuaba con los preparativos de las Olimpíadas Populares, cuya inauguración estaba prevista para el 19 de julio de 1936, el mismo día en que Air France tenía previsto inaugurar la línea aérea que unía Lisboa con Barcelona y Palma. Aquellas Olimpiadas eran un gran evento deportivo, de calado turístico, orientado a proyectar la ciudad de Barcelona a través de actividades deportivas y culturales, como venía haciendo en los años previos, una vez fracasado su intento de obtener la candidatura de los Juegos Olímpicos, que se llevó Berlín. Tenían también un alto componente ideológico de protesta frente a la propaganda hitleriana y a aquella olimpiada berlinesa. ${ }^{20}$

En el otro extremo del país, en Panxón, pueblo de veraneo en la ría de Vigo, sucedía otro tanto. Allí concurrían «numerosas familias de distintas partes de la región y muchas de Madrid a dejar sus pesetas» desde hacía bastantes temporadas, ${ }^{21}$ y lo volvieron a hacer en el verano de 1936, al margen

18. Moreno (2007a y 2007b). AGA, Cultura, 12.559.

19. Johnstone (2016), p. 138.

20. Santacana y Pujadas (1990) y Palou (2012), p. 252

21. El Pueblo Gallego, 19 de agosto de 1933. 
de - o conviviendo con - la intensa movilización de las organizaciones sindicales pesqueras y agraristas que allí actuaban, reclamando mejores precios para la sardina o la supresión de los foros agrarios. Esa «normalidad» fue cortada el 18 de julio por el golpe militar de Franco y su Movimiento Nacional.

Salvo excepciones, estallada la guerra, los extranjeros que veraneaban en las islas Baleares y en la costa mediterránea o atlántica abandonaron sus destinos por sus propios medios, viendo que «la cosa iba para largo» y «crecía la inquietud» entre los turistas, o fueron evacuados en barco por sus respectivos países en dos o tres semanas. Sucedió así en la provincia de Gerona o en las Baleares, donde la armada británica desempeñó un papel destacado. En San Feliu de Guíxols y en Tossa, por ejemplo, fue un destructor británico el que recogió a los que quisieron irse, al fin casi todos. «Los turistas ingleses, que estaban convencidos de que se libraban de una muerte segura por la providencial intervención de la armada británica, corrían que se las pelaban para subir a bordo. [...] Los marineros que habían desembarcado se despidieron de las bellezas de Tossa. La gente del pueblo contempló en silencio la marcha precipitada de sus visitantes». ${ }^{22} \mathrm{El} 27$ de julio, por ejemplo, fueron evacuados desde Barcelona y otros puertos de Cataluña hacia Marsella 785 personas en barcos de Su Majestad, de ellas 544 británicos, 144 suizos y 40 norteamericanos. En San Sebastián, donde el estallido de la guerra cogió al cuerpo diplomático británico desplazado desde Madrid en su tradicional veraneo a esta «summer capital», la colonia británica y otros extranjeros eran evacuados entre el 23 y el 27 de julio hacia territorio francés - San Juan de Luz, Hendaya-, por carretera - unas 250 personas - y por mar en tres buques de la armada británica, el Veteran, el Venty y el Keppel. ${ }^{23}$

También se cortaron las salidas de los españoles al exterior. Portugal fue uno de los damnificados. El turismo español hacia allí tenía tradición decimonónica. Modesto Fernández dejó constancia de ello en su magnífico diario de viaje Portugal contemporáneo (1874) y Miguel de Unamuno en su libro Por tierras de España y Portugal, de 1911. En el primer tercio del siglo Xx, en efecto, destinos como Figueira da Foz debieron mucho de su brillo a los españoles y «sobretudo, as espanholas»; pero este flujo español se vio interrumpido por la Guerra Civil de 1936-1939, «circunstancia que dejó marcas visibles en la sociedad local, posteriormente evocadas por Jorge de Sena en la novela Sinais de Fogo». Igual sucedió en otros destinos como Praia da Rocha, que se resintieron ante este retroceso del mercado español. En general, la guerra en España afectó negativamente a la corriente turística externa hacia Portugal, por la «mala vecindad» que representaba. ${ }^{24}$

22. Johnstone (2016), pp. 147-151.

23. Documents on British Foreign Office Policy 1919-1939, 1979.

24. Pina (1988), pp. 45, 47 y 79. 
En el primer verano de la guerra, muchos de los españoles que hacían turismo veraniego en el país lo siguieron haciendo en medio de la zozobra, de las primeras resistencias y movilizaciones populares, de las primeras represiones, en medio, en fin, de una guerra que percibieron, tanto desde la España ocupada como de la leal a la República, en muchos casos lejana y con la esperanza de que fuera breve. En el centro estival de Panxón (Pontevedra), el día 5 de agosto, «a las seis de la tarde llega el rumor de que los comunistas izan la bandera roja en el Sindicato de Marineros de Panjón. Se oían los gritos y los lloros en alto de las mujeres, el vecindario y los bañistas escapaban por entre las dunas; el suegro del maestro de Panjón tuvo que refugiarse en un horno al ver los grupos armados detrás de él». Pero pese a estos esporádicos episodios bélicos, allí el 12 de septiembre de 1936 «en general continúan las prácticas de veraneo y baño, alteradas por la realidad de la guerra y de la conflictividad bélica o política de las primeras semanas de la guerra. Una nueva realidad se sedimenta: los crucifijos vuelven a las escuelas en septiembre». ${ }^{25}$ Y con ellos, en esta España ocupada por los nacionales, se impusieron los discursos remoralizadores, opuestos a las prácticas de libertad alcanzadas desde las décadas de los veinte en torno a las playas y el ocio turístico, discursos especialmente virulentos con las mujeres que vinieron de la mano de algunas facciones falangistas y sobre todo de la Iglesia católica. En abril de 1937, el obispo de Tui (Pontevedra), se preguntaba «¿hasta cuándo...?» respecto a la liberación femenina y a sus prácticas recreativas:

La inmodestia de la mujer en sus vestidos: vestidos de casa y de calle, de sociedad y de iglesia, de teatro y de playa... Pero ¿es posible que la mujer cristiana y española, en estas horas trágicas que nuestra amadísima Patria vive y sufre, siga siendo frívola y sensual y sus vestidos indecorosos y sus posturas y ademanes inverecundos y sus deportes paganos y su conducta en las playas y balnearios lúbrica y descocada? ${ }^{26}$

Estos discursos, en todo caso, no hay que confundirlos con una posición ideológica o política de las élites dirigentes de la España nacional contra el turismo como actividad económica. Esta identificación, efectuada en bastantes trabajos sobre el turismo de estos años, es errónea. Impide entender muy poco de lo que sucede en la economía turística y en las expectativas y objetivos que movieron, en este plano, a las autoridades turísticas del Nuevo Estado, tanto durante la guerra como, sin solución de continuidad, después de la misma. El turismo se redujo de forma drástica no por la posición política dominante antiturística del bando vencedor. La Guerra Civil, primero, con sus

25. El Pueblo Gallego, 6 de agosto de 1936, p. 8, y 12 de septiembre de 1936, p. 9.

26. Boletín Oficial del Obispado de Tuy, 5, 3 de mayo de 1937, p. 118. 
secuelas a corto plazo, y la guerra mundial, a continuación, fueron las responsables del hundimiento turístico del país. Las circunstancias internacionales se impusieron, agravando los efectos que la propia guerra interior había iniciado en el turismo en España.

\section{Desplome del turismo durante la Guerra Civil}

¿Qué sucedió durante la guerra con el turismo como práctica social y como actividad económica? En lo económico, la respuesta es obvia: las actividades económicas turísticas se hundieron. El sector entró en crisis pronunciada. Ahora bien, encontramos marcados matices locales. Durante la guerra, al fin larga, en materia de turismo constatamos realidades diferenciadas al menos por cinco factores: el bando en el que cayó cada provincia, la distancia a los frentes (zonas de vanguardia o retaguardia), los abastecimientos disponibles, los desplazamientos excepcionales de población provocados por el conflicto, que dieron una vitalidad inédita a la hostelería de bastantes ciudades españolas, ${ }^{27}$ y, por supuesto, la intensidad o componente previo del turismo en las distintas provincias y localidades. En Baleares, por ejemplo, ya se vio que con la guerra venía el retroceso turístico. El carácter isleño, por un lado, y el alto componente internacional del mercado turístico, intermediado o canalizado en buena medida por operadores turísticos foráneos (navieras, agencias de turismo), por otro, revelaron de inmediato la inviabilidad turística mientras la guerra persistiera. Allí los turistas extranjeros eran algo más del cincuenta por ciento del turismo total en los primeros años treinta. ${ }^{28} \mathrm{Y}$ del turismo español, poco cabía esperar, atenazado por el conflicto y obstaculizado en su movilidad por el estricto control ejercido con la implantación de los «salvoconductos». La Memoria de la Cámara provincial de Comercio dejó de publicar desde su edición correspondiente a 1936 las estadísticas de turismo, simplemente porque el levantamiento militar provocó el hundimiento turístico.

Pero ¿cuánto se hundió el turismo? Una primera respuesta la tenemos en el gráfico 1, que representa la intensidad mediática del turismo desde 1900 hasta 1955: en 1936, un $28 \%$ respecto a 1935 y, en 1937 , un $95 \%$ respecto a 1936 . El gráfico nos muestra también que ese hundimiento persistió durante 1938 y, algo más atenuado, durante 1939, en que vemos un cierto repunte, que coincide con las expectativas generadas entre la ciudadanía española por el fin de la guerra y el deseo revelado por varios agentes turísticos internacionales de volver a ofrecer el destino español, pese a lo reciente de la guerra y a varios obstáculos y carencias. Lo expresa bien la campaña de la agencia Pickfords Travel Service en

27. Aunque la hostelería es parte significada del sector turístico, este boom bélico extraordinario no ha de considerarse en sentido estricto turístico.

28. Cirer (2009), p. 268. 
1939: «Why not SPAIN or PORTUGAL this year?», donde estaban garantizadas unas «sunshine and inexpensive holiday», o el hecho de que en París varias agencias de viajes ofertaran en sus escaparates imágenes y productos turísticos de España. La Dirección General de Turismo seguía atenta el interés turístico por España, pese al escenario de nueva guerra mundial. En una información del director en funciones de la Office National Espagnol de Tourisme en París dirigida a Luis A. Bolín, el 6 de noviembre de 1939, se decía que había seis agencias de viajes que «exponen en sus escaparates y vitrinas folletos, carteles y fotografías relacionados con el turismo en España». Se trataba de la Agencia Oficial de los Ferrocarriles Suecos Nordisk, ULTRATOURS, Mon Voyage, Bureau de Voyages des Guides Bleus, Voyages Modernes y de Wagons-Lits-Cook (Casa Central en Brd. Des Capuceines), que tenía «expuesto una maqueta en relieve de España que obra en nuestro poder y forma parte de la decoración de esta Agencia». ${ }^{29}$

Pero esas expectativas fueron efímeras al estallar la guerra mundial en septiembre. El turismo tardaría en reanimarse; solo a partir de 1948-1949 volvió a manifestar signos inequívocos de recuperación, coincidiendo con el inicio del restablecimiento del turismo europeo posbélico, aunque no fue hasta 1954 cuando de forma clara se superaron los índices de intensidad turística máximos del período republicano, correspondientes a 1934. El turismo se muestra, como revela la experiencia histórica e internacional, sensible a las restantes variables económicas, que no recuperaron en el caso español los niveles previos a la guerra hasta 1953-1954, como sabemos.

El gráfico 1 también ofrece un dato que pudiera ser relevante: en Galicia, incorporada desde julio de 1936 a la España nacional, la intensidad mediática del turismo es mayor que en la media española durante 1936-1938. Todo parece indicar que el dato es extrapolable, como posible indicativo del comportamiento diferencia regional, según las provincias estuvieran en uno u otro bando. En las islas Canarias, por ejemplo, se constata que siguieron llegando cruceros, hasta el punto de que la agencia de turismo Camacho, en Santa Cruz de Tenerife, prestó asistencia a once «vapores de recreo» extranjeros entre el 17 de junio y el 26 de diciembre de $1938 .{ }^{30}$ Las provincias del bando nacional parecen, pues, haberse comportado mejor, en cuanto al turismo como práctica social y también como actividad económica; así lo revela el comportamiento de la hostelería, que experimentó incluso cierto boom, por el aumento excepcional de desplazados provocado por el propio conflicto, aunque no quepa hablar aquí de flujos estrictamente turísticos. La guerra quebró, pues, la normalidad, y esta quiebra también desestructuró el sistema turístico en formación, como ahora veremos.

30. Cerchielo (2017), p. 101. 


\section{Desestructuración del sistema turístico español entre 1936 y 1939}

Desde su estallido, la Guerra Civil repercutió negativamente en el sistema turístico español, esto es, en sus agentes individuales, los viajeros o turistas en sus distintas modalidades, y colectivos, en las asociaciones turísticas, la administración turística y, en general, en la organización turística española, incluido, claro está, el conjunto de empresas familiares o corporativas que suministraban servicios a los viajeros, pues cabe hablar de un sistema turístico cuando todos esos elementos están presentes, con mayor o menor intensidad y difusión (cuadros 4 y 5).

\section{CUADRO 4 - Sistema turístico}

\begin{tabular}{|c|c|}
\hline \multicolumn{2}{|c|}{ Destinos y productos } \\
\hline \multicolumn{2}{|c|}{ Mercado (informal, formal) } \\
\hline \multirow{5}{*}{ Agentes } & - Turistas (consumidores) \\
\hline & - Asociaciones de turismo activo \\
\hline & - Asociaciones de turismo receptivo \\
\hline & - Administración \\
\hline & - Empresas (oferentes) \\
\hline Organiza & urística \\
\hline
\end{tabular}

Fuente: Elaboración propia.

CUADRO 5 - Agentes del sistema turístico español, 1900-1939

1. Turistas (bañistas, agüistas, veraneantes, excursionistas, turistas)

2. Organismos de turismo activo: Asociaciones excursionistas, clubs de alpinismo, Reales Automóviles Club; clubs de ciclistas; asociaciones de camping

3. Organismos de turismo receptivo: Sindicatos de Iniciativa o Sociedades de Fomento del Turismo

4. Empresas o «industria turística»: 1) Balnearios; 2) Industria hotelera; 3) Industria de restauración; 4) Empresas de transporte: trenes, tranvías, funiculares, vehículos (garajes), autobuses, navieras, aviones; 5) Empresas especializadas en ocio y atracciones para forasteros; 6) Agencias de viaje; 7) Empresas urbanizadoras

5. Sector informal de alojamiento

6. Administración turística: 1) Estatal; 2) Municipal; 3) Provincial; 4) Autonómica

Fuente: Elaboración propia. 
La desestructuración afectó, por tanto, a todos los niveles y actores de aquel sistema en vías de consolidación desde al menos 1928. En primer lugar a los y las turistas, esto es, a los ciudadanos, nacionales y extranjeros, y sus posibilidades de viajar por España u otros países, que se vieron dificultadas, obstaculizadas o simplemente anuladas. Las prácticas turísticas continuaron más en los ámbitos locales, con las experiencias tradicionales de veraneo o excursionismo de corto radio. Surgieron, no obstante, nuevas modalidades turísticas como el turismo de guerra, espontáneo u organizado (cuadro 6). A este segundo fueron invitados especialmente los extranjeros, en las rutas o viajes propagandísticos financiados, y también en las Rutas Nacionales de Guerra, un particular producto turístico de la España nacional, sobre el que luego volveremos. La guerra provocó un nuevo tipo de viajero, ya conocido en guerras anteriores: el desplazado, el huido o refugiado. Las infraestructuras del transporte y de alojamiento (de familias, empresas y organizaciones públicas e incluso no gubernamentales), se pusieron al servicio de este viajero forzoso. Este generó posibilidades excepcionales de negocio para la hostelería existente, que desaparecieron tan pronto como la guerra llegó a su fin.

El llamado turismo activo ${ }^{31}$ se vio seriamente debilitado. Las posibilidades de trasladarse en excursiones, en forma de caravanas automovilísticas o en transportes colectivos se redujeron. Faltaron combustibles, muchos puentes fueron destrozados y en general las carreteras o las infraestructuras ferroviarias se deterioraron. Las prioridades sociales eran ahora otras, sin que desapareciera la afición al viaje de placer o al veraneo, ya arraigados en sectores relativamente amplios de las clases medias urbanas o de la clase alta. Un indicador lo podemos ver en la páginas del Butlletí del importante y socialmente elitista Centre Excursionista de Catalunya (gráfico 3). Este, tras la profunda crisis de actividad que siguió a la implantación de la República, en 1931-1933, vivió una época de notable reactivación en 1934-1936; pero el estallido de la guerra le volvió a afectar severamente. Como había sucedido en 1931-1932,

\section{CUADRO 6 - Viajeros y turistas durante la guerra}

Viajeros y turistas tradicionales: Excursionistas, veraneantes, agüistas, bañistas, viajantes de comercio y turistas

Turistas de guerra:

a) Viajes espontáneos, individuales o familiares

b) Viajes individuales o colectivos financiados institucionalmente

c) Viajes colectivos mercantilizados, organizados oficialmente

Viajeros forzosos: Desplazados, huidos, refugiados, represaliados, etc.

Fuente: Elaboración propia.

31. Para estos conceptos, Muntanyola (1932) y Vallejo (2018, en prensa). 
GRÁFICO 3 - Número de páginas anuales del Butlletí del Centre Excursionista de Catalunya, 1893-1938

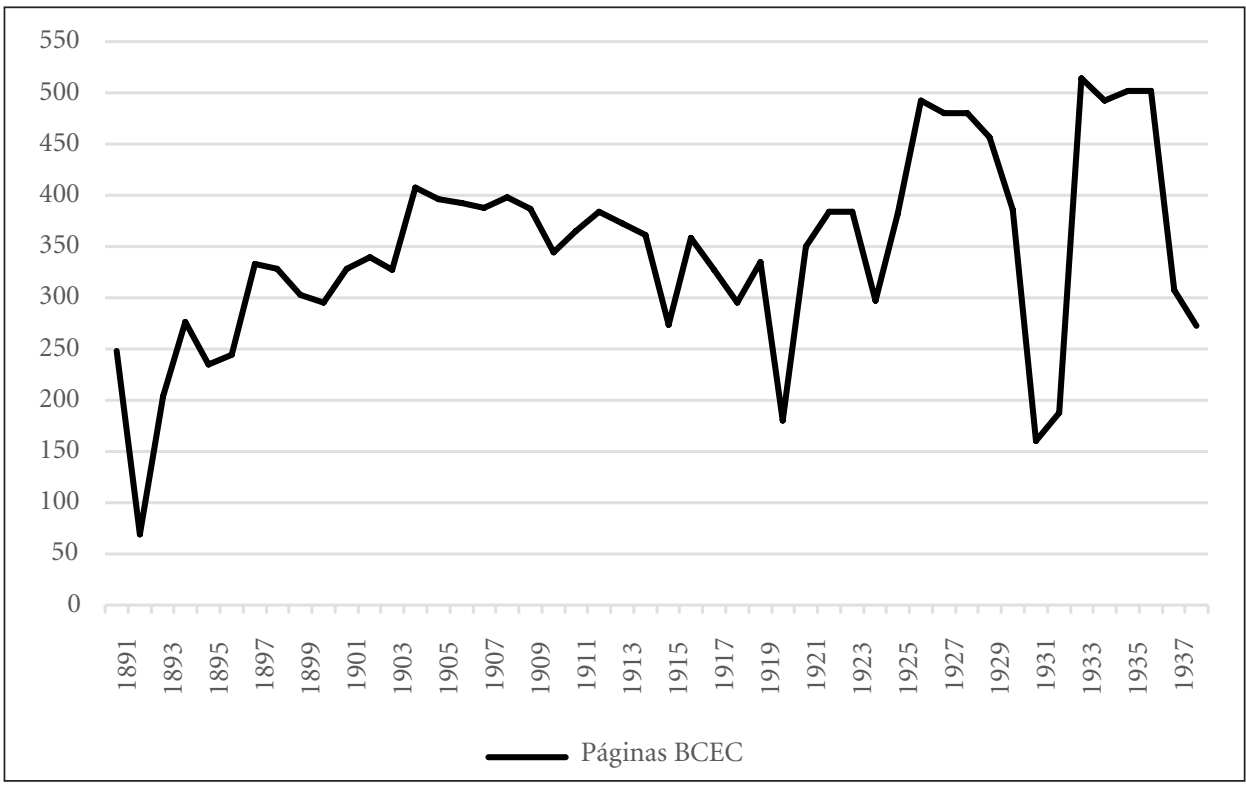

Fuente: Elaboración propia a partir del Butlletí.

las páginas de su Butlletí se redujeron de forma sustancial en 1937 y en 1938, al igual que las excursiones del Centre, sus publicaciones o sus convocatorias a los socios, en medio de las penurias y el clima bélico sufrido en Barcelona. La caída de la ciudad ante el avance de las fuerzas leales a Franco acabó con la publicación del Butlletí.

En cuanto al llamado turismo receptivo (organización receptiva para fomento y propaganda), el fermento asociativo y organizativo experimentado por los Sindicatos de Iniciativa Turística (SIT) durante la República se vio severamente afectado. La Federación de los SIT, declarada organización de utilidad pública en 1935, paralizó sus actividades, en tanto que asociaciones consolidadas y prestigiosas como Fomento del Turismo de Barcelona (1908-1936) cortaron sus iniciativas. Su publicación Barcelona Atracción (1908-1936) se clausuró en agosto de 1936, y otro tanto sucedió con su magnífico Anuario o su colección de monografías turísticas. La razón radica en que el 31 de marzo de 1937, la Conselleria d'Economía de la Generalitat «s'apropia de la Sociedad de Atracción de Forasteros, intervenint totes les seves dependències i adscrivint al servei d'aquesta Conselleria l'arxiu, biblioteca, fitxers i tota altra documentació». ${ }^{32}$

32. Disposición recogida por Palou (2012), p. 258. 
Barcelona Atracción reapareció en 1945, con afán de continuidad, visible en su tipografía y formato, pero ahora no como una publicación de la sociedad civil organizada, en la órbita sociológica de la Lliga Catalana, quien la controlaba en último extremo, sino como una publicación oficial. La revista pasó a depender de la Junta Provincial de Turismo, una junta ciertamente con personalidad propia, como correspondía a una ciudad de la potencia económica, la historia y la tradición turística de Barcelona, aunque sometida al estrecho dictado de la Dirección General de Turismo del Nuevo Estado. «BARCELONA ATRACCIÓN era la Revista de la Sociedad de Atracción de Forasteros, y en 1936 desapareció como tantas y tantas otras cosas, que no volveremos a ver como estaban», sostuvo Manuel Ribé en el número que abría su nueva época en 1945.

Ribé no era un neófito en la materia. Había sido uno de los inspiradores de la Sociedad de Atracción de Forasteros de Barcelona, presidente de la Federación de Sindicatos de Iniciativa de Cataluña (1932-1936), y era considerado, en marzo de 1936, un «hombre ejemplar, que ha luchado entusiásticamente toda la vida por el turismo». ${ }^{33}$ ¿Qué había sucedido? Que, como otros hombres del nacionalismo catalán conservador en la órbita de la Lliga, apoyaron el Movimiento Nacional; siguiendo el ejemplo de Francesc Cambó, colaboraron en las entretelas de su aparato institucional durante la guerra, con desigual grado de implicación, claro está, y se incorporaron, una vez acabada aquella, a las instituciones del Estado franquista. En el ámbito del turismo catalán y español, Ribé es un ejemplo, entre otros. Tenemos aquí un hilo para entrever o, sin más, para identificar los elementos de continuidad, en este caso humanos, en el sistema turístico español de antes de la guerra y el que siguió tras la misma, con menos rupturas de fondo que las aparentes a primera vista. La guerra fratricida dejó cadáveres, heridos y excluidos por el camino, es evidente. Fue un drama social. Pero no evitó las continuidades, aunque estas queden ocultas por la parafernalia del Movimiento Nacional, los brazos en alto y muchos símbolos de la nueva y autoritaria situación, que se pretendió totalitaria. Algo similar a lo de Barcelona vemos en Valencia, con la Sociedad Valenciana Fomento del Turismo y su órgano de difusión Valencia Atracción (1922-1936). Esta revista también dejó de publicarse en julio de 1936 y reapareció en 1945, ${ }^{34}$ cuando, al finalizar la Segunda Guerra Mundial, se abrían los «momentos que pueden ser precursores de un desarrollo intenso del turismo en España», como presumía y deseaba el director general de Turismo Luis A. Bolín en mayo de 1945. ${ }^{35}$

33. Barcelona Atracción, 301, 1936, p. 200.

34. Valencia Atracción, año XI, número 119, julio 1936; y Valencia Atracción (2. época), año 20, 120, marzo de 1945.

35. Barcelona Atracción (2a época), año XXVII, mayo de 1945, s.p. 
Mejor fortuna - permítasenos la licencia- corrieron durante la guerra las potentes asociaciones formadas en Palma de Mallorca (Fomento del Turismo, 1905) o en Zaragoza (Sindicato de Iniciativa y Propaganda de Aragón, 1925), pues ambas ciudades quedaron en el ámbito de la España nacional. Fomento Balear continuó, en medio de la zozobra y las dificultades, con sus actividades, velando por los intereses turísticos de la isla y su empresariado, pese a la caída de ingresos y la baja de socios desde los primeros meses de la contienda, en espera de que las condiciones permitieran recuperar el dinamismo turístico vivido desde los años veinte por Mallorca, que había experimentado ya su primer gran boom histórico hasta 1934-1935. Alguno de sus hombres destacados desempeñó un importante papel en el organigrama de la organización turística del Estado franquista en formación. Es el caso de Francisco Vidal Sureda, que había sido asesor de la efímera Dirección General de Turismo de 1931 y presidente de la Federación Española de Sindicatos de Iniciativa desde 1932. Ocupó un lugar destacado en la implementación de las Rutas de Guerra (1938-1939), el 6 de marzo 1939 asumió la dirección de la Oficina de Turismo de París del Gobierno nacional y, poco después, se encargó de las oficinas provinciales de turismo en Mallorca, donde fue el mayor «propagandístico turístico». ${ }^{36}$

El Sindicato de Iniciativas y Propaganda de Aragón (SIPA), por su parte, mantuvo su publicación Aragón, la única gran revista de turismo ligada a una asociación de fomento editada durante la guerra, pues las otras dos, Valencia Atracción y Barcelona Atracción desaparecieron, como vimos. Ahora bien, sus contenidos estrictamente turísticos decayeron, de acuerdo con la situación general, y mantuvo su componente «artística». La propaganda, la exaltación y adhesión a las autoridades del nuevo régimen formaron el nuevo tono de la publicación y del SIPA. Pero sus páginas también reflejaron las expectativas y la situación de las organizaciones turísticas en el escenario de guerra nacional e internacional desde 1939.

Nuestra labor en el año 1937, ha sido la siguiente: Las circunstancias especiales por que atraviesa la nación española han contribuido a la paralización de la industria del turismo, pero como nuestra función no está limitada a un tiempo fijo, seguimos nuestra actuación cumpliendo la misión que las actuales circunstancias imponen, en espera de que en una próxima fecha; liberado todo el territorio nacional del yugo del marxismo, podamos desarrollar ampliamente nuestras actividades con la atención puesta siempre en los altos intereses de la patria. ${ }^{37}$

36. Sobre Vidal, Bolín (1967), p. 313; Fernández Fuster (1991), p. 320; Correyero y Cal (2008), pp. 250-255, y Buades (2004), p. 91. AGA, Cultura, 10832.

37. Aragón, febrero de 1938, p. 39. 
Cualquier especialista riguroso del turismo de estos años no puede dejar de consultar las páginas de la revista Aragón de 1936 a 1945 para identificar el espíritu y las posibilidades turísticas de la época, las aspiraciones y los límites impuestos por la realidad económica y la nueva realidad política, cuando no eran «en verdad las actuales circunstancias las más propicias para el feliz desenvolvimiento de las actividades turísticas» y «toda suerte de dificultades y obstáculos» se venían «interponiendo en el afán de viajar que la sociedad actual experimenta», y se imponía, en fin, «la hora del trabajo recogido y silencioso dedicada a organizar, difundir y mejorar el turismo, con vistas a un mañana próximo».$^{38}$ Entre esas expectativas encontramos el papel que los SIT desearon desempeñar en la organización turística del Nuevo Estado, no muy distinto al previo: información y propaganda, reconocimiento como entidades de utilidad pública y, por tanto, parte de la organización turística oficial, con soporte en la financiación pública — local y gubernamental—, y con un fin patriótico ahora añadido: el servicio al Nuevo Estado salido de la guerra. También varias de las personalidades del SIPA (caso de Enrique Celma) sumaron su historia personal a la causa de la llamada «reconstrucción nacional». Ellos y el SIPA como organización reclamaron, así, para los sindicatos de iniciativa, su lugar bajo el tibio sol del primer franquismo en la remozada organización turística del país, algo que consiguieron en cierto modo.

Las empresas (industrias turísticas) experimentaron igualmente el impacto extraordinario de la guerra. Las compañías de comunicaciones y transportes terrestres, las navieras y la incipiente aviación se vieron afectadas por las circunstancias extraordinarias, al igual que la hostelería, los balnearios y la naciente red de establecimientos públicos de alojamiento, y se pusieron al servicio de la economía de guerra, como gran parte de las organizaciones y equipamientos del país.

Esta afectación fue diferente, según los sectores concretos y los territorios. Los impactos fueron desiguales en función de los factores arriba mencionados, a veces azarosos. Lo vemos en la hotelería. La de la España sublevada parece haber aguantado bien el embate de la guerra, a tenor del número de establecimientos abiertos y tributando por Contribución Industrial y de Comercio, que resistieron casi tal cual, o incluso aumentaron su número. Lo vemos en la ciudad de Córdoba hasta 1939, momento en que se inició un cierre de establecimientos, incluidos dos hoteles, cuyo número - cinco, según la estadística fiscal - no se volvió a recuperar hasta 1942. El caso de Santiago de Compostela, que también hemos analizado, es parecido al de Córdoba.

38. Enrique Celma, «El año turístico», Aragón, noviembre-diciembre de 1941, pp. 94-96. 
GRÁFICO 4 - Hoteles y casas de huéspedes en Córdoba, 1926-1959

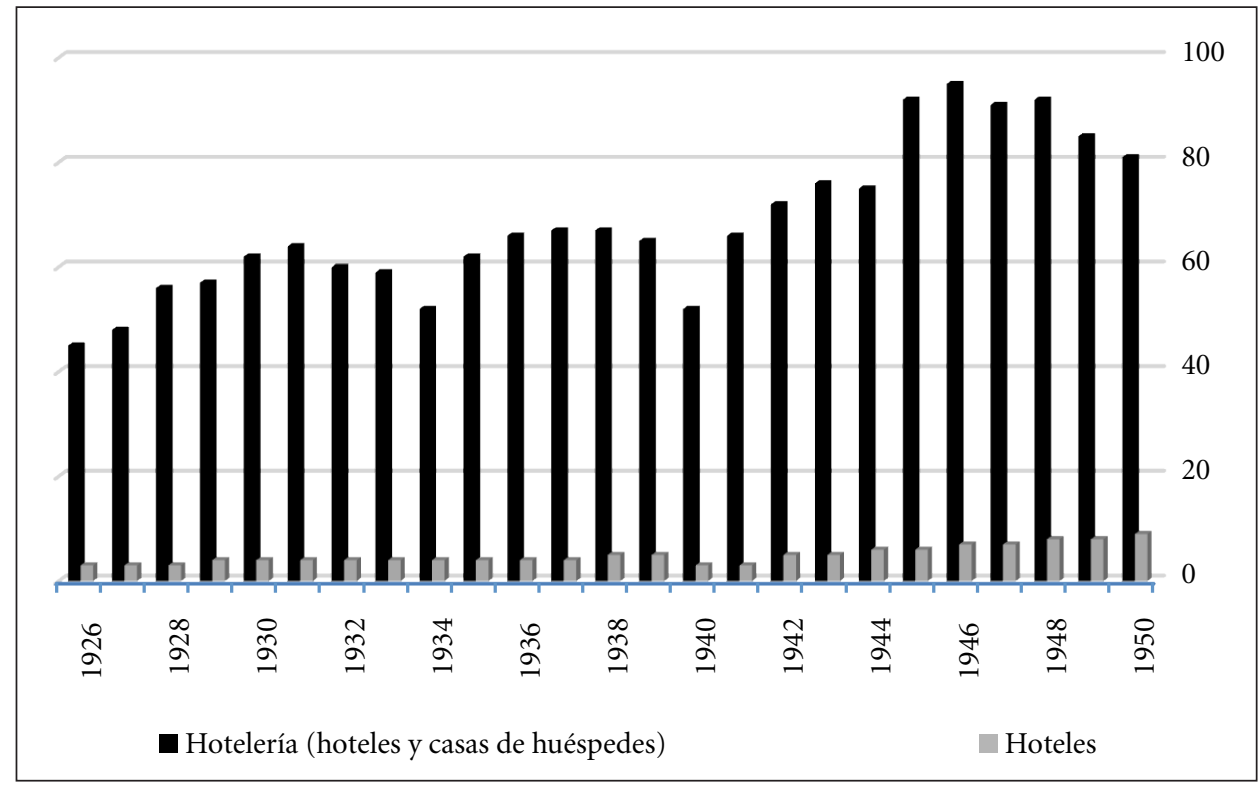

Fuente: Archivo Histórico Provincial de Córdoba, Matrícula de la Contribución Industrial y de Comercio del municipio de Córdoba. Varios años.

El comportamiento de la hostelería de Burgos, capital de la «España de la Cruzada» en 1936-1939, ejemplifica muy bien los beneficios extraordinarios provocados por la guerra y no entrevistos previamente, pues, como señaló el gobernador civil el 28 de julio de 1937:

... los rendimientos de esa industria se han triplicado durante el año de la guerra, con relación al año anterior, triplicidad explicable por cuanto el plazo de explotación en Burgos, de esa industria, tenía como su "agosto" los tres meses de verano, plazo que se ha hecho extensivo a los doce meses del año, a virtud de unas dolorosas, aunque gloriosas circunstancias que, por lo que tienen de dolorosas, no pueden ser motivo de alegría industrial para ningún ciudadano. ${ }^{39}$

Los 46.000 habitantes habituales de Burgos llegaron a 100.000 en aquellos años: militares, políticos nacionales y extranjeros, desplazados por el conflicto, refugiados, heridos, corresponsales de guerra, diplomáticos, funcionarios, etc., se dieron cita en la ciudad. Los precios de la hotelería se dispararon.

39. Bando de Antonio Almagro, gobernador civil de Burgos, 28 de julio de1937, Archivo Municipal de Burgos, 15-2449, s/f. 
La construcción de hoteles licitada en 1934 o 1935 no se detuvo. Se inauguraron varios en plena guerra, como el Hotel España (1938) y el Hotel Condestable (1938). Incluso se abrió el llamado Refugio Nacional, desde el 31 de julio de 1937 hasta el 6 de agosto de 1939, para acoger a desplazados de postín (empresarios, grandes propietarios, jerarcas de la nueva situación, aristócratas) en su «comedor y aquellos dormitorios, a la altura de su nivel social». ${ }^{40}$ Aquella episódica centralidad de la ciudad castellana sirvió para una extraordinaria proyección internacional de la misma; su función tradicional de ciudad histórico-monumental y nudo de comunicaciones quedó reforzada con esta circunstancial capitalidad política.

Otro caso igualmente destacable fue el de San Sebastián, republicana hasta septiembre de 1936 y desde entonces bajo el control militar de los sublevados. En un clima de restricción de libertades, se recuperaron las actividades turísticas en 1937, con reapertura de negocios y atracciones para los turistas, una recuperación más visible en 1938 y 1939. A través del brillo tradicional de San Sebastián, el régimen, que instaló allí parte de sus servicios centrales turísticos desde 1938, uso el turismo en la capital donostiarra como instrumento de propaganda turística, para dar una imagen - en parte falsa- de la «normalidad» en que vivía la España nacional. Lo explicó muy bien una crónica periodística de 1939: en San Sebastián «la sensación de normalidad, de ausencia del histórico traumatismo bélico y social, de incorporación a los modos europeos, eran, de hecho un gran elemento de seducción y de propaganda» ${ }^{41}$

De modo parecido a Burgos y en cierto modo a San Sebastián, en la España nacional otras ciudades como Salamanca, Valladolid o Vigo tuvieron la hostelería llena de gente durante la guerra y hubo dificultades para que los desplazados pudieran encontrar alojamiento. No faltaron, no obstante, casos de cierres hoteleros. En Palma de Mallorca, por ejemplo, el Gran Hotel no pudo afrontar la parálisis provocada por el período bélico. Fue un símbolo del desplome turístico isleño. Málaga, por el contrario, pese al drama de la violenta toma y de la dura represión que siguió a la misma en 1937, se comportó en 1938 como «típicamente ciudad de invierno», constataba el destacado funcionario del SNT Luis Pérez-Moliner, desplazado a ella mientras dicho servicio funcionó desde allí, y jefe de la Sección de Rutas de Guerra inauguradas en julio de $1938 .{ }^{42}$ Según él:

Los turistas [de estas Rutas], aparte del coste del viaje, dejan mucho dinero en los comercios y en las industrias típicas que visitan en cada región. A un gran hotel

40. Refugio Nacional de Burgos 1937-1939, Archivo Municipal de Burgos, MS-16.

41. El Diario Vasco, 5 de mayo de 1939, p. 6.

42. Carta de Pérez-Moliner, de la DGT, a J. Bosch, de Pickfords Travel Service, de Londres, 2 de octubre de 1939. AGA, Cultura, Caja 12034. 
del Norte, que por circunstancias especiales llevaba una vida difícil el año pasado, le proporcionamos con nuestras excursiones un ingreso de más de 30.000 pesetas. A ciento veintitantos hoteles dieron viajeros las "rutas" el año pasado. ${ }^{43}$

Así pues, las necesidades extraordinarias de alojamientos suscitados por la movilización de guerra, los desplazamientos o huidas de población desde la España republicana a la nacional, o dentro de la España republicana (lo vemos en Almería, por ejemplo), así como la promoción de algunos productos, como las Rutas Nacionales de Guerra, sirvieron para mantener e incluso desbordar la ocupación hotelera entre 1936 y 1939.

Los equipamientos hoteleros, como otros bienes físicos o de capital, fueron objeto de uso extraordinario y puestos al servicio de la economía de guerra. La hotelería española, sobre todo los grandes hoteles, contaba a aquella altura con edificios referentes por la calidad de sus instalaciones y adelantos técnicos, como las telecomunicaciones, que eran emblemas de un determinado estatus social de privilegio. Por eso en la España republicana estuvieron sometidos a las decisiones de los comités revolucionarios desde las primeras semanas de la contienda, cuando guerra y revolución corrieron parejas. Llegaron a ser confiscados y convertidos en cuarteles generales de los comités sindicales o de los partidos revolucionarios para albergar órganos de gobierno o representación política, delegaciones extranjeras, etc.

Así sucedió en Barcelona, donde empresarios como Miquel Regás, un referente en la industria hotelera catalana, perdieron el control de sus establecimientos. En 1880, afirmó algún patrón de la hostelería, el obrero no contaba nada en el negocio hotelero, en tanto que en 1936 era el patrón quien no contaba, primero por el sistema de relaciones laborales favorable a los trabajadores de la hostelería menos cualificados y peor remunerados impulsado tras el triunfo del Frente Popular, luego por las colectivizaciones efectuadas tras el estallido de la Guerra Civil. En julio de 1937, la Dirección General de Seguridad, desde Valencia, dictó normas, de acuerdo con el Comité Unificado de la Industria Hotelera, para regular los servicios de «dicha industria». Se establecían dos tumos laborales para cafés, bares y hospederías, de 19 a 9 horas y de 9 a 23 horas, se fijó el horario de comidas y se prohibió la venta de bebidas alcohólicas. ${ }^{44}$

En algunos pueblos de la Costa Brava, por su parte, varios establecimientos hosteleros fueron usados como colonias infantiles, amparadas por la organización International Solidarity Fund, para acoger niños procedentes de

43. Carta de Pérez-Moliner a Bolín (29 de septiembre de 1939), AGA, Cultura, 12378.

44. Solidaridad Obrera, 1 de agosto de 1937, p. 5. Para las colectivizaciones en Barcelona, muy casuísticas, véase Miguelsanz (2009). 
poblaciones situadas en las líneas de frente. ${ }^{45}$ Otros hoteles fueron convertidos, a su vez, en hospitales de sangre, como sucedió en Málaga con el gran Hotel Miramar, ya antes de caer la ciudad en manos de los «fascistas» en febrero de 1937. No faltaron asimismo las destrucciones de hoteles por ataques de la aviación y la artillería, como sucedió con el Hotel Savoy de Madrid o el Hotel Inglés de Barcelona, entre otros. ${ }^{46}$

Los balnearios experimentaron igualmente las circunstancias extraordinarias del período; en ellos, la actividad ordinaria del enfermo, del bañista o del agüista se frenó, y muchos fueron convertidos, voluntaria o coactivamente, en hospitales o acuartelamientos ${ }^{47}$ Otro tanto sucedió con la incipiente red de establecimientos públicos del PNT (albergues de carretera y paradores), sometidos a cambiantes usos militares u hospitalarios por uno u otro bando, según la variable situación de los frentes. ${ }^{48}$

Otras empresas que participaban directa o indirectamente de aquel sistema turístico en proceso de consolidación sufrieron igualmente los impactos de la guerra. En unos casos su actividad se paralizó totalmente. Lo vemos en las iniciativas de las sociedades urbanizadoras en destinos turísticos en las provincias de Barcelona, Gerona, Alicante o Palma de Mallorca. Las «empresas de transporte» fueron intervenidas y puestas al servicio de la guerra. Un ejemplo es el de Transmediterránea, cuya flota quedó dividida entre ambos bandos y experimentó pérdidas por bombardeos y hundimientos de barcos, al igual que la Compañía Ibarra o la Aznar. Sufrieron, con ello, los servicios específicos para turistas. El crucerismo, en boga en los años treinta pese a la crisis internacional, se hundió pues las navieras internacionales desaparecieron de casi todos los puertos españoles, exceptuados los canarios, como se dijo.

Esta parálisis bélica afectó igualmente a la industria de intermediación de viajes. Uno de sus corolarios fue, en este ramo de las agencias y en el de la hostelería o el transporte turístico, el paro forzoso de los trabajadores. La $\mathrm{Me}$ moria anual de la Cámara de Comercio Industria y Navegación de Palma de Mallorca recogió, desde 1937, datos de «paro obrero» en «transportes terrestres», «transportes marítimos» y «hostelería». A 30 de septiembre de 1939, la «industria hotelera» registraba un paro de 144 hombres y 10 mujeres. En 1940, en Mallorca «la industria hotelera siguió dando escaso, casi nulo, rendimiento, motivado al conflicto internacional, que, continuador de nuestro Movimiento Nacional, siguió paralizando la concurrencia del turismo, espe-

45. Como vemos en la Casa Jonhstone, en Tossa de Mar, Johnstone (2016), p. 321 y ss.

46. AGA, 33, F, 04039, 53238, 001; Luis Sierra, «Las bombas no se olvidan», La Vanguardia, 17 de marzo de 2013.

47. Para una perspectiva general, Vilar y Lindoso (2019, en prensa); para Mondariz, requisado para hospital militar durante la guerra, Gurriarán (2015), p. 175.

48. Rodríguez (2014), p. 239. 
rando que acallados los aires bélicos que imperan, tomará el auge que ha tenido en pasadas épocas, convirtiendo a Mallorca en una de las principales zonas del turismo mundial». ${ }^{49}$

Los impagos o las pérdidas de empleo se encadenaron. Así, por ejemplo, los empleados en París de la agencia de viajes española FAVE, S.A., nacida en 1933 de un consorcio entre Viajes Marsans, Cafranga, Iberia y Carco, perdieron en 1937 su empleo, sin recibir explicación o comunicación alguna de su compañía, en un principio. Esto sucedía mientras, por otra parte, los experimentados directivos de estas empresas, algunos con cierta experiencia política previa, bajaban abiertamente a la contienda política y bélica. Dos destacados, Marsans y Eusebio Cafranga (este con pasaporte portugués), se pusieron al servicio de los «facciosos», al viajar repetidamente a Francia o Inglaterra. ${ }^{50}$

Otras de las personalidades del turismo español, sin embargo, desaparecieron en medio de las dificultades empresariales o resultaron muertos. En febrero de 1937 fueron fusilados en el cementerio de Palma de Mallorca los vocales de Fomento del Turismo Emili Darder (excalcalde de la ciudad), Antonio María Ques y Antoni Mateu (exalcalde de Inca), así como el exdiputado socialista Alexandre Jaume, miembro del Grupo Parlamentario pro Turismo en las Cortes republicanas y uno de los defensores allí del turismo balear. Nadie fue inmune a los desastres de la guerra. En enero de 1938, la suerte corrida por los directivos de los sindicatos de iniciativa era la siguiente: «... algunos [...] han sido muertos y otros han podido escaparse o siguen sin novedad» ${ }^{51}$ Varios de estos cualificados supervivientes colaboraron, desde la España del Movimiento Nacional, a construir la organización turística del Estado emergente, con los mimbres humanos e institucionales heredados de la España republicana y, por extensión, de la dictadura primorriverista, y se incorporaron a ella acabada la guerra.

La guerra desestructuró, por tanto, la organización y la política turística. La partió por la mitad, la orientó hacia funciones de propaganda, tanto en los organismos de los respectivos Gobiernos centrales como en el autonómico de la Generalitat o del efímero Gobierno vasco. Y respecto a sus recursos humanos, a las mujeres y a los hombres que trabajaban al servicio del turismo en las flamantes oficinas de turismo, juntas provinciales de turismo y departamentos centrales del Patronato Nacional de Turismo - y también del organismo oficial de la Generalitat de Catalunya-, se impusieron la repre-

49. Memoria Comercial anual de la Cámara Provincial de Comercio, Industria y Navegación de Palma de Mallorca, correspondiente a 1937, 1939 y 1940, pp. 149, 166 y 124, respectivamente.

50. AGA, Cultura, Caja 10832.

51. Reunión de la Junta Directiva de Fomento del Turismo de Mallorca, 4 de enero de 1938, Libro III de Actas de la Junta Directiva 1929-1945. 
sión, las fugas, las pérdidas de empleo y las dramáticas pérdidas humanas fruto de la violencia en medio del fragor bélico.

A partir de enero de 1938, no obstante, en el bando nacional se impulsó la reconstrucción, en medio de su ofensiva, de su salto adelante con la renovada institucionalidad gubernamental, que recuperaba el organigrama ministerial al uso, marcada por la Ley de Administración Central del Estado, de 30 de enero de 1938, y la constitución al día siguiente del llamado Gobierno de Burgos, en la que se veía a sí misma ya como una política de construcción del «Nuevo Estado». En materia de organización turística, este impulso se hizo con dos movimientos, recuento de tropas y reorganización, al servicio de la reconstrucción. Con un director único: Luis Bolín, militar y propagandista muy próximo a Franco, asesorado de destacados dirigentes del PNT monárquico o republicano, caso de José Antonio Sangroiz, que había sido secretario general del mismo y, en octubre de 1936, jefe del Gabinete y del Protocolo del Jefe del Estado, Franscisco Franco, en Salamanca. ${ }^{52}$

La reconstrucción de la administración turística impulsada por Bolín y Arturo Garau era continuista respecto a la vigente en 1936, esto es la del Patronato Nacional de Turismo. Según Garau, el secretario general del llamado en 1938 Servicio Nacional de Turismo (SNT), «la organización establecida [...] es buena como lo demuestra el hecho de que no hayamos procedido a su reforma» ${ }^{53}$ Había que recuperarla, ponerla a pleno funcionamiento, con un principio rector: «....asegurar la actuación eficaz de este servicio en la reconstrucción de España y en la preparación del país para el turismo nacional y extranjero». ${ }^{54}$ Bolín y sus colaboradores más estrechos sabían que España había llegado a 1936 como país emergente en el turismo internacional. En consecuencia, sus acciones como autoridades turísticas del Nuevo Estado tuvieron muy presentes los objetivos de, vuelta la normalidad, recuperar los flujos turísticos interiores y exteriores de antes de la guerra y, sin solución de continuidad, situar a España en el mercado turístico mundial, como uno de sus líderes, aunque los efectos de la Guerra Civil primero y el estallido de la Segunda Guerra Mundial a continuación lo impidieron.

52. Carta de José Antonio de Sangroniz al marqués de la Vega Inclán, en Salamanca, a 15 de octubre de1936, Inventario: FD3051 (ceres\mcu).

53. Carta de Garau, firmada en el SNT, en Málaga, el 16 de marzo de 1939, AGA, Cultura.

54. La expresión es de un proyecto de organización del SNT, de 2 de mayo de 1939, pero aplicable al organismo desde sus orígenes. AGA, Cultura, 12094. 


\section{Guerra y nuevas formas de turismo: los tres turismos de guerra}

La Guerra Civil provocó una situación excepcional durante tres años. Rompió la normalidad de la vida cotidiana. Esta ruptura afectó a las prácticas de ocio, a los viajes, a su frecuencia y a sus modalidades. Una de estas modalidades se ha etiquetado como turismo de guerra. El fenómeno no era nuevo ni exclusivo de España. Sobre él se ha vertido mucha tinta y ha recibido muchas denominaciones: Dark Tourismo, Thana-tourism, etc. ${ }^{55}$ No vamos a profundizar en ello aquí. El hecho, en cualquier caso, es que en la España de 1936 a 1939 aparecieron tres tipos de turismos de guerra, como referimos en el cuadro 2. El primero es de los viajes espontáneos, individuales, familiares o en pequeños grupos a los frentes de guerra; el segundo, el de los viajes individuales o colectivos al país, para conocer la situación de sus gentes y acudir a los escenarios de la guerra, financiados institucionalmente; en tercer lugar tenemos los viajes colectivos mercantilizados, organizados oficialmente, a los paisajes castigados por la guerra, que en el caso español recibieron el nombre de Rutas de Guerra. Por su relevancia, dedicaremos a este el siguiente apartado.

Los viajes espontáneos a los frentes de guerra surgieron al poco de estallar la misma. Lo vemos bien en la provincia de Madrid, en el frente de la sierra del Guadarrama. Los protagonizaron los propios nacionales radicados en las ciudades. La publicación Ahora los denominó «estos bravos turistas de la emoción guerrera». En la provincia de Madrid, en efecto, «los caminos que conducen a la Sierra se habían convertido en pistas de turismo para algunas gentes ávidas de emociones». Buscaban «noticias directas» del frente, aunque mantenían una «respetable distancia» al mismo; se alimentaban sobre todo de rumores. Estos «turistas de la sierra» practicaban en todo caso un «deporte insensato». Las autoridades militares de la República acabaron prohibiéndolo, limitando el tráfico, pues el vehículo a motor (el turismo) era su medio de transporte. Temían que entre ellos se colase una quinta columna de espías al servicio del bando sublevado. ${ }^{56}$ Este de la sierra de Madrid es un ejemplo, entre otros, de ese particular turismo de guerra, tanto en la España republicana como en la España de los nacionales.

Otra modalidad dentro de este turismo, menos espontáneo, es la del periodista de guerra que, en la España nacional, viaja por los lugares o ciudades «liberadas». Estamos en este caso ante un propagandista que hace un particular turismo interior, para contar a sus conciudadanos, en tono a veces

55. Holguín (2005).

56. Ahora, 29 de julio de 1936, p. 3. Entre estos turistas de guerra espontáneos había grupos de milicianos que salían de Madrid sin dirección militar, deseosos de ver lo que sucedía en el frente. Arturo Barea da testimonio de ello en La forja de un rebelde, III. 
desenfadado, la «verdad» subjetiva de lo que ha visto, mezclándose «con las gentes que surgen de los encierros de once meses, con los que alcanzan la felicidad del primer pan blanco que regalan nuestras tropas y con los que salen cautamente ¡a ver qué pasa!». Es lo que hace para el $A B C$ de Sevilla un tal Juan Deportista, en su crónica «Tres jornadas bilbaínas, tras las horas de liberación. Donde siento plaza de turista», porque este deportista califica su relato no como «crónicas de guerra» sino «como las impresiones del primer turista en Vizcaya redimida»..$^{77}$

¿Qué trascendencia económica tiene esta modalidad de turismo? Es probable que escasa. Pero refleja, sin embargo, unas prácticas sociales surgidas con la guerra que crearon sensaciones intensas a los partícipes y, seguro, una corriente de opinión publicada dirigida a inducir, con la crónica periodística, un estado de ánimo en la población de la España nacional y de la España republicana. También esas crónicas, presentadas como relatos viajeros, turísticos, estaban al servicio de la guerra psicológica.

Más claramente al servicio de la guerra psicológica e ideológica estuvo la segunda modalidad de turismo de guerra aludida, la de los viajes individuales o colectivos inducidos y financiados institucionalmente con fines propagandísticos. Sus partícipes o beneficiarios fueron mujeres y hombres destacados, personalidades, de los países de nuestro entorno; su fin, generar relatos, a partir de la experiencia vivida en la España en guerra, más o menos mediatizada por el control del anfitrión, para ganar las opiniones públicas de sus respectivas naciones y el concurso de sus Gobiernos al triunfo de la causa propia, fuese la de la República o, en su caso, la de la España que se decía auténticamente nacional. Esta modalidad de turismo de guerra promovido oficialmente era parte del instrumental de guerra de los bandos enfrentados, aunque quienes lo han estudiado señalan que el Gobierno de la República se prodigó más en él. ${ }^{58} \mathrm{Su}$ financiación fue público-privada en el bando sublevado y fundamentalmente pública en la España leal a la República. Nos extenderemos en esta segunda, porque en el bando nacional fue más visible y aparente la tercera modalidad de turismo de guerra, el de las Rutas Nacionales.

Como se explicó arriba, frente al turismo como actividad económica, durante la guerra tuvo mucho más peso relativo el turismo como propaganda. Sucedió en el interior del país; en las delegaciones turísticas o diplomáticas en el exterior, como vimos ocurría en la Oficina del PNT en París del Gobierno republicano hasta 1939, donde el personal y las funciones turísticas quedaron relegadas por las funciones propagandísticas, que llevaban cargos nombrados expresamente por el ministro de Estado o la presidencia de la República.

57. $A B C$, edición de Sevilla, 30 de junio de 1937, p. 6.

58. Son destacables los trabajos de Hugo García; por ejemplo, García (2006) y Rodríguez (2008). 
De estos servicios de propaganda, interiores y exteriores, dependió la parte sustancial del turismo de guerra patrocinado por las autoridades republicanas. Imposibles las divisas turísticas, había que promover viajes con financiación pública destinados a promocionar el Gobierno legítimo de España ante los Gobiernos occidentales, ganar voluntades para la causa republicana. El soporte para ello fue una activa propaganda elaborada por varios agentes y medios. Por un lado, las agencias específicas creadas con este fin, como la Agence Espagne (octubre de 1936), en manos de expertos propagandistas extranjeros, caso del alemán Willy Münzenberg; por otro, las delegaciones de propaganda, como la de París, al mando de Juan Vicens (desde julio de 1937), ubicada en la Oficina de Turismo de España, reconvertida ahora en agencia al servicio de la guerra. ${ }^{59}$

En tercer lugar tenemos el testimonio difundido a través de los medios de comunicación de masas de la época (cartelería, prensa, radio, cine) por mujeres y hombres de reconocida reputación social, intelectual o política («stars»), tras su paso por los frentes, el contacto con la realidad española, o la intervención en congresos internacionales, invitados por el Gobierno de la República a esta particular forma de turismo de guerra, no siempre de forma bien organizado, por la dispersión de medios y autoridades e indudablemente por las precarias o perentorias circunstancias desde las que se promovían estas iniciativas. ${ }^{60}$ Un ejemplo de este turismo de guerra financiado por el Gobierno republicano lo tenemos en el célebre II Congreso Internacional de Escritores en Defensa de la Cultura, celebrado en Valencia, Madrid, Barcelona y París en julio de 1937, al que asistieron escritores como Malraux, Ehrenburg, Julien Benda, Stephen Spender y Malcolm Cowley.

También sirvieron a ese mismo fin otros grandes eventos y exposiciones, como la Internacional de París en 1937. En ella, el atractivo pabellón español racionalista diseñado por Josep Lluís Sert y Luis Lacasa expuso el Guernica de Picasso y otras obras artísticas de los notables Julio González, Alberto Sánchez, Joan Miró, Josep Renau y Alexander Calder. La participación española en dicha exposición había sido concebida en 1935 para «hacer valer, a los ojos de las representaciones y visitantes de los demás países, las distintas manifestaciones de la producción de arte típico español y, sobre todo, el valor turístico que encierra nuestro país». Pero la guerra la convirtió en espacio para la "propaganda de nuestra causa» ${ }^{61} \mathrm{Al}$ igual que transformó los escenarios de las batallas en el interior del país en paisajes para un turismo mer-

59. En contra de la opinión de los arrendatarios, que adujeron el contrato para evitar una oficina de propaganda al servicio de la República.

60. El efímero Gobierno autonómico vasco (1936-1937) y la Generalitat de Cataluña crearon sus servicios propios de propaganda.

61. Archivo General de la Guerra Civil española (Salamanca), PS-Madrid, Caja 1704, Leg. 4491. 
cantil propagandístico, promovido y monopolizado por las autoridades de la España nacional: las Rutas de Guerra.

\section{El turismo bélico del Servicio Nacional de Turismo: las Rutas de Guerra (1938-1939)}

La de las Rutas de Guerra es la modalidad de turismo mejor conocida de estos años de la contienda, hasta el punto de que ha sido casi identificada como la única forma de turismo. No fue así, como vimos. Pero es sin lugar a dudas la más llamativa y también la más estudiada. ${ }^{62}$ Por ello aquí solo ofreceremos una breves notas para destacar, en primer lugar, que fue conciba como un producto turístico, al servicio de la causa de la España nacional de Franco, cuando iniciado 1938 los vientos de la guerra soplaban a su favor, una vez caídos los territorios fieles a la República en el norte, afianzados los avances del bando rebelde y puesta en marcha su institucionalización como Nuevo Estado. Como se explicó arriba, la reorganización de la administración turística, en el Ministerio del Interior, con el nombre de Servicio Nacional de Turismo, formó parte de la «reconstrucción nacional», al igual que los circuitos o Rutas Nacionales de Guerra implementadas desde el SNT y publicitadas ya desde mayo de 1938.

La idea inicial era poner en marcha cuatro rutas. Se quedaron en dos. La del Norte, la más importante, iniciada en el verano de 1938, pese a las dificultades para aprovisionarse de los autobuses Dodge americanos, y la de Andalucía, prevista para el 1 de diciembre de 1938.

Sus objetivos fueron tres. El propagandístico resultó el más relevante, para difundir la versión o verdad «nacional» de la guerra y ofrecer una imagen de normalidad en la España «reconquistada». El segundo y el tercero eran económicos. Se trataba de obtener algunas divisas para, muy modestamente, colaborar a sostener el esfuerzo de guerra y, en las provincias que las autoridades franquistas llamaban liberadas, ofrecer posibilidades de negocio a las agencias de viaje fieles al régimen de Franco y a algunos establecimientos de hostelería y tiendas de productos típicos o recuerdos del país. Las cifras manejadas por quienes las han estudiado ponen de relieve que los ingresos de las rutas favorecieron casi más a las empresas implicadas (sobre todo a los hoteles y a las agencias de viajes que vendieron el producto) que al incipiente Estado franquista; cuestión distinta fue el impacto psicológico y la fuerza propagandística que las Rutas de Guerra tuvieron, esto es, sus valores intangibles.

62. Véanse Correyero y Cal (2008), Pack (2009) y Concejal (2014). 
CUADRO 7 - Balance económico de las Rutas Nacionales de Guerra, 1938-1940

\begin{tabular}{lcc}
\multicolumn{1}{c}{ Balance económico } & 1938-1939 (18 meses) & $\mathbf{1 9 4 0}$ \\
\hline Ingresos totales & 1.302 .533 & 597.675 \\
Abonado a los hoteles (\%) & 35,4 & 37,3 \\
Otros gastos (\%) & 43,8 & 54,8 \\
Beneficios líquidos (\%) & 20,8 & 8,0
\end{tabular}

Fuente: Elaboración propia a partir de Correyero y Cal (2008).

\section{Conclusiones}

La Guerra Civil supuso una quiebra de la normalidad socioeconómica y, con ella, la ruptura de la normalidad turística, en un país en el que capas cada vez más amplias de la población se habían incorporado a las prácticas turísticas, que empezaba a figurar, según algunas de las cifras internacionales disponibles, entre los países turísticos (receptores) emergentes. En este trabajo hemos aportado evidencias para demostrar que esto es fundamental para entender la cesura generada por la guerra en la materia tratada en este artículo.

La guerra cortó, sí, la consolidación del sistema turístico en formación durante el primer tercio del XX, acelerada desde 1928 hasta 1936, y paralizó la organización turística existente en 1936. De este modo, la política turística quedó mermada en sus posibilidades y, sobre todo, desbordada por la realidad de la guerra. La labor estricta de promoción económica del turismo quedó relegada a un segundo plano. Ganó peso el papel del turismo al servicio de la propaganda exterior, para generar adeptos y, en fin, para ganar la guerra. Cuando la llamada España nacional, iniciado 1938, vio las posibilidades de vencer la contienda, sin perder de vista ese papel propagandístico del turismo, inició la labor de reconstrucción de la organización turística para que el turismo, llegada la «normalidad» en el Nuevo Estado deseado, volviese también a la normalidad. Esto significaba convertir sus divisas en una partida significativa de los ingresos externos, como se vislumbraba inmediatamente antes de la guerra, cuando España era una nación que se mostraba como destino turístico emergente y, como tal, era reconocida por importantes operadores internacionales. Por ello, primero con el Servicio Nacional de Turismo (1938) y después con la Dirección General de Turismo (1939), la España de Franco optó por la recuperación de la organización y de la política turística siguiendo el molde de la existente durante la República, y la puso al servicio de la construcción del Nuevo Estado y de la reconstrucción de la España que querían los rectores del mismo.

Por otra parte, aunque las prácticas turísticas retrocedieron necesariamente durante la contienda, con desigual intensidad provincial, no se habían olvida- 
do. Los usos y costumbres turísticos en los años previos a la Guerra Civil no se circunscribían a las élites del poder y del dinero, pues se habían ido difundiendo paulatinamente entre estratos más amplios de la población española. Hemos estimado que más de un millón de españoles y españolas de las clases medias (empleados de «cuello planchado», que decía Arturo Barea, funcionarios, comerciantes, profesiones liberales, etc.) se habían estado incorporando a alguna de las modalidades de viaje o práctica turística en la España republicana y en la segunda mitad de la década de 1920. Aunque pensando muchas veces en el público extranjero, la mayor parte de las infraestructuras y de los servicios turísticos creados en España durante la segunda mitad del siglo XIX y en las primeras décadas del siglo xx tenían como principales usuarios a los nacionales.

Además, acabada la guerra, lo fundamental del sistema turístico en formación antes de 1936, bien fueran destinos, geografías turísticas o el tejido empresarial al servicio del viaje y de la estancia de placer en un lugar diferente al de la vida cotidiana, permanecía ahí, por más que hubo destrucción y pérdidas definitivas durante el conflicto. Al fin y al cabo, la España de 1936 disponía de un patrimonio turístico y una experiencia empresarial acumulada, un saber hacer que, pese a sus limitaciones relativas, poco tenían que ver con los de 1900. Desde el punto de vista turístico, estamos ante otro país. Por eso será posible constatar que en 1946 Mallorca volvió a alcanzar los máximos de preguerra en cuanto a número de turistas llegados, que en 1953-1955 se alcanzaron, y superaron, los diversos indicadores de intensidad turística previos a la Guerra Civil, y que, al fin, el país consiguió situarse entre los líderes turísticos a principios de los años 1960. Y no necesariamente a consecuencia de la política turística, aunque esta ayudó, ni solo por los cambios socioeconómicos en la Europa desarrollada tras la Segunda Guerra Mundial. El «milagro turístico» español debió mucho a la senda turística que se había inaugurado antes de 1936.

\section{Bibliografía}

Bolín, L. (1967). España: los años vitales. Madrid: Espasa-Calpe.

BuAdes, J. (2004). On brilla el sol. Turisme a Balear abans del boom. Eivissa: Res Publica.

Cerchiello, G. (2017). La evolución de los cruceros marítimos en España. Desde sus comienzos hasta la actualidad (1848-2016). Valencia: PUV.

Cirer, J. C. (2009). La invenció del turisme de masses a Mallorca. Palma de Mallorca: Documenta Balear.

Concejal, E. (2014). «Las Rutas de Guerra del Servicio Nacional de Turismo (19381939)». En: Visite España. La Memoria rescatada, Madrid: BNE, pp. 259-273.

Correyero Ruiz, B. (2000). «Apuntes para el Primer Crucero Transatlántico a la España Nacional (1939)». Historia y Comunicación Social, n. ${ }^{\circ}$ 5, pp. 75-87. 
Correyero Ruiz, B.; CAL, R. (2008). Turismo: la mayor propaganda del Estado. España: desde los orígenes hasta 1951. Madrid: Visión Net.

Escalas, J. (1933). Mallorca, Guía ilustrada. Palma de Mallorca: Galerías Costa.

FArreras, A. (1973). El turismo a Catalunya del 1931 al 1936. Barcelona: Pòrtic.

FERnÁNDEZ Fuster, L. (1991). Historia general del turismo de masas. Madrid: Alianza.

GArcía, H. (2006). «El turismo político durante la Guerra Civil: viajeros británicos y técnicas de hospitalidad en la España republicana, 1936-1939». Ayer, 64/2006, n. ${ }^{\circ} 4$, pp. 287-308.

García Álvarez, J. (2011). «Geografía, propaganda y turismo en la España de la postguerra: la Revista Geográfica Española». XII Coloquio de Geografía del Turismo, Ocio y Recreación.GurRiarán, R. (2016). Enrique Peinador Lines e Mondariz. Empresa, turismo e país. Vigo: Foro Enrique Peinador / Pío García Edicións.

Holguín, S. (2005). «National Spain invites you: Battlefield tourism during the Spanish Civil War». The American Historical Review, vol. 110, n. ${ }^{\circ}$ 5, pp. 1399-1426.

Johnstone, N. (2016). Un hotel en la Costa Brava. Barcelona: Tusquets (título original, Hotel in Spain, 1937).

Lavaur, L. (1980). «Turismo de entreguerras: (1919-1939) (II)». Revista de Estudios Turísticos, . $^{\circ}$ 68, pp. 13-129.

Leveillé-Nizerolle, C. (1938). Le Tourisme dans l'économie contemporaine. París: Librairie de Recueil Sirey.

Lickorish, L.; Kershaw, A. G. (1958). The Travel Trade. Londres: Practical Press Ltd.

Miguelsanz Arnalot, À. (2009). Parada i fonda. L'hostaleria de la Ciutat. Del origins als nostres dies. Barcelona: Labeltur.

Moreno Cantano, A. C. (2012). «Propaganda y neutralidad: la proyección de la España franquista en Suiza (1936-1945)». Coetánea. Actas del III Congreso Internacional de Historia de Nuestro Tiempo. Logroño: Universidad de la Rioja, pp. 227-236.

Moreno Garrido, A. (2007a). «L'Office de Tourisme Espagnol de París (1929-1936). Política y turismo en los años treinta». Cuadernos de Historia Contemporánea, n. ${ }^{\circ}{ }^{29}$, pp. 199-218.

- (2007b). Historia del turismo en España en el siglo XX. Madrid: Síntesis.

Muntanyola, A. (1932). Organització turística de Catalunya. Barcelona: Arts Gràfiques l'Estampa.

Norval, A. J. (1936). The tourist industry. Londres: Sir Isaac Pitman \& Sons Ltd.

Ogilvie, F.W. (1933). The tourist movement. An economic study. Londres: P.S. King \& Son Ltd.

PACK, S. D. (2009). La Invasión pacífica: los turistas y la España de Franco. Madrid: Turner.

Palou i Rubio, S. (2012). Barcelona, destinació turística. Un segle d'imatges i promoció pública. Bellcaire d'Empordà: edicions Vitel·la.

Pardo Abad, C. J. (2013). Territorio y recursos turísticos. Madrid: Centro de Estudios Ramón Areces. 
Pellejero, C. (1999). «Antecedentes históricos del turismo en España: de la Comisión Nacional al Ministerio de Información y Turismo, 1900-1950». En: Pellejero, C. (dir.), Historia de la economía del turismo en España. Madrid: Civitas, pp. 21-76.

- (2000), El Instituto Nacional de Industria en el sector turístico. Atesa (1949-1981) y Entursa (1963-1986). Málaga: Universidad de Málaga.

PinA, P. (1988). Portugal. O turismo no século XX. Lisboa: Lucidus Publicaçoes.

Rodríguez, M. C. (2008). «La Mémoire du franquisme dans l'Espagne postfranquiste: les symboles de L'Hispanidad mis en évidence par le «tourisme de guerre» ont-ils servi le silence et l'oubli?». En : Hähnel-Mesnard, C., et. al. (eds.), Culture et mémoire: représentations contemporaines de la mémoire dans les espaces mémoriels, les arts du visuel, la littérature et le théâtre. Palaiseau : Les Editions de l'Ecole Polytechnique, pp. 145-154.

Rodríguez PÉRez, M. J. (2014). «La red de alojamientos turísticos del Estado». Visite España. La Memoria rescatada. Madrid: BNE, pp. 223-241.

Santacana, C.; Pujadas, X. (1990). L’altra Olimpíada. Barcelona’36. Esport, societat i política a Catalunya (1900-1936). Badalona: Llibres de l'Índex.

VAllejo Pousada, R. (2015). «¿Bendición del cielo o plaga? El turismo en la España franquista, 1939-1975». Cuadernos de Historia Contemporánea, n. ${ }^{\circ}$ 37, pp. 89-113.

- (2019). «Turismo en España durante el primer tercio del siglo xx: la conformación de un sistema turístico». Ayer (en prensa).

Vallejo Pousada, R.; Lindoso Tato, E.; Vilar Rodríguez, M. (2016). «Los antecedentes del turismo de masas en España, 1900-1936». Revista de la Historia de la Economía y de la Empresa, n. ${ }^{\circ} 10$, pp. 137-188.

VILAR, M.; Lindoso, E. (2018). «De la Belle Époque a la nueva era del turismo termal: los balnearios en España desde una perspectiva histórica (1874-2015)». Ayer (en prensa).

Vives Reus, A. (2005). Historia del Fomento del Turismo en Mallorca (1905-2005). Palma de Mallorca: Foment del Turisme de Mallorca. 


\section{Tourism during the Spanish Civil War, 1936-1939: the impact of war on a burgeoning tourist system}

\section{ABSTRACT}

This paper is based on several assumptions: tourism as an economic activity and as a social practice in Spain during the first third of the twentieth century was more significant than is generally assumed; prior to the Civil War, the foundations of the contemporary Spanish tourism system were being laid; in 1936 Spain was evidently, from the international figures available, an emerging tourist destination on the global tourism market.

The paper is organized in five sections. The first presents the lines of development in Spanish tourism between 1900 and 1936, and how a particular tourism system is configured. The second shows, with several indicators, the tourism situation in the first quarter of 1936 and the tourism collapse from the second semester of 1936 to the end of 1939, with its local variants. The third section presents the fundamental features of the negative impact of the war on the incipient Spanish tourism system. The fourth and fifth sections explain how the war gave rise to new forms of tourism, described as war tourism, and explain what lies behind each of these forms.

KeYwords: Spain, tourism, Civil War

JEL CODES: N74, L83, O16

\section{Turismo durante la Guerra Civil, 1936-1939: el impacto de la guerra en un sistema turístico en formación}

\section{RESUMEN}

Este trabajo parte de varios supuestos: el turismo como actividad económica y como práctica social en España durante el primer tercio del siglo xx es más importante de lo que generalmente se presupone; hasta la Guerra Civil, se están poniendo las bases del sistema turístico español contemporáneo; en 1936 España se muestra, mediante las cifras internacionales disponibles, como un país turístico emergente en el mercado turístico global.

Se organiza en cinco apartados. El primero presenta las líneas de evolución del turismo español entre 1900 y 1936 y cómo se configura un particular sistema turístico. El segundo muestra, con varios indicadores, la coyuntura turística en el primer semestre de 1936 y el desplome turístico desde el segundo semestre de 1936 hasta finales de 1939, con sus variantes locales. El tercero indica los rasgos fundamentales de la desestructuración provocada por la guerra en el incipiente sistema turístico español. El cuarto y el quinto exponen cómo la guerra dio lugar a nuevas modalidades de turismo, calificadas de turismo de guerra, y se explica qué hay detrás de cada una de estas modalidades.

Palabras Clave: España, turismo, Guerra Civil

Códigos JEL: N74, L83, O16 


\section{Fe de erratas}

\section{Revista de Historia Industrial, 75}

\section{Página 101}

DONDE DICE

1.300.000 españoles turistas, un $5,5 \%$ de la población total

pasó del puesto trigésimo en 1931

CUADRO 1 - Composición del turismo en España, 1931-1934

\begin{tabular}{|c|c|c|c|}
\hline Turistas & $\begin{array}{c}\text { Turistas } \\
\text { totales en } \\
\text { España, } \\
\text { 1931-1934 } \\
\text { (media } \\
\text { anual) }\end{array}$ & $\%$ Total & $\begin{array}{c}\% \\
\text { Población } \\
\text { española }\end{array}$ \\
\hline $\begin{array}{l}\text { Receptivo: } \\
\text { Extranjeros }\end{array}$ & 142.500 & 9,6 & 0,6 \\
\hline $\begin{array}{l}\text { Interno: } \\
\text { Españoles } \\
\text { en España }\end{array}$ & 1.118 .562 & 75,7 & 4,7 \\
\hline $\begin{array}{l}\text { Emisor: } \\
\text { Españoles en } \\
\text { el extranjero }\end{array}$ & 215.721 & 14,6 & 0,9 \\
\hline Turismo total & 1.476 .783 & 100,0 & 6,2 \\
\hline
\end{tabular}

\section{DEBERÍA DECIR}

1.500 .000 españoles turistas, un $6,4 \%$ de la población total

pasó del puesto decimotercero en 1931

CUADRO 1 - Composición del turismo en España, 1931-1934

\begin{tabular}{|c|c|c|c|}
\hline Turistas & $\begin{array}{l}\text { Turistas } \\
\text { totales en } \\
\text { España, } \\
\text { 1931-1934 } \\
\text { (media } \\
\text { anual) }\end{array}$ & $\%$ Total & $\begin{array}{c}\% \\
\text { Población } \\
\text { española }\end{array}$ \\
\hline $\begin{array}{l}\text { Receptivo: } \\
\text { Extranjeros }\end{array}$ & 195.100 & 10,0 & 0,8 \\
\hline $\begin{array}{l}\text { Interno: } \\
\text { Españoles } \\
\text { en España }\end{array}$ & 1.531 .449 & 78,8 & 6,4 \\
\hline $\begin{array}{l}\text { Emisor: } \\
\text { Españoles en } \\
\text { el extranjero }\end{array}$ & 215.721 & 11,1 & 0,9 \\
\hline Turismo total & 1.942 .269 & 100,0 & 8,1 \\
\hline
\end{tabular}

